\title{
Plantas utilizadas na medicina popular brasileira com potencial atividade antifúngica
}

\author{
Raquel Fenner ${ }^{1}$, Andresa Heemann Betti ${ }^{1}$, Lilian Auler Mentz ${ }^{2}$, Stela Maris Kuze Rates ${ }^{1}$ \\ ${ }^{1}$ Faculdade de Farmácia, Universidade Federal do Rio Grande do Sul, ${ }^{2}$ Departamento de Botânica, Instituto de \\ Biociências, Universidade Federal do Rio Grande do Sul
}

*Correspondência:

S. M. K. Rates

Faculdade de Farmácia - UFRGS,

Laboratório de Psicofarmacologia

Av. Ipiranga 2752,

90610-000 - Porto Alegre, RS, Brasil

E-mail: ratessmk@farmacia.ufrgs.br
Neste trabalho foi realizado um levantamento bibliográfico etnobotânico sobre plantas utilizadas pela população brasileira no tratamento de sinais e sintomas relacionados às infecções fúngicas. Foram citadas 409 espécies, distribuidas em 98 famílias, com maior concentração em Fabaceae e Asteraceae. Para as dez espécies mais citadas, foi realizada uma busca relativa a estudos de atividade antifúngica na base de dados MEDLINE-PubMed. Somente foram encontrados estudos para Phytolacca americana $L$., Rosmarinus officinalis $L$., Mirabilis jalapa $L$., Schinus molle L. Entre as dez espécies mais utilizadas, seis correspondem a espécies nativas: Anacardium occidentale $L$., Cecropia peltata $L$., Schinus molle L., Schinus terebinthinfolius Raddi, Stryphnodendron adstringens (Mart.) Coville $e$ Tabebuia heptaphylla (Vell.) Toledo.
Unitermos

- Plantas medicinais

- Atividade antifúngica

- Uso tradicional

\section{INTRODUÇÃO}

Ao longo dos últimos anos, a ocorrência de infecções fúngicas humanas vem apresentando um aumento expressivo, sendo as dermatomicoses as principais infecções responsáveis por esse aumento. Vários fatores estão relacionados ao crescimento dessas infecções fúngicas, entre eles: o melhor diagnóstico laboratorial e clínico, o aumento da sobrevida de pacientes com doenças imunossupressoras e o emprego de medicamentos imunossupressores, utilizados às vezes de forma abusiva, permitindo a instalação de microorganismos convencionalmente saprófitos (Sidrim et al., 1999).

Os fungos responsáveis por essas infecções são fungos patógenos (Epidermophyton, Microsporum, Trichophyton, Paracoccidioides, Histoplasma) ou fungos patógenos oportunistas (Candida albicans, Cryptococcus neoformans). O tratamento das micoses humanas não é sempre efetivo, pois os fármacos antifúngicos disponíveis produzem recorrência ou causam resistência, além de apresentarem importante toxicidade. Por esta razão, há uma busca contínua de novos fármacos antifúngicos mais potentes, mas, sobretudo, mais seguros que os existentes. Além das infecções em humanos, os animais também podem ser atacados esporadicamente por fungos muito difíceis de serem combatidos. Além disso, as infecções fúngicas em plantas (espécies de Rhizoctonia, Phytophtora, Sclerotinia, Fusarium, Phomopsis, Colletotrichum, Diaphorte, Macrophomina, Cercospora) representam perdas incalculáveis para a produção agrícola (Zacchino, 2001).

Neste contexto, embora a maioria dos antifúngicos existentes no mercado seja de origem sintética, o estudo de produtos naturais voltou a receber a atenção dos cientistas (Yunes, Filho, 2001). Entre as principais ferramentas 
na busca de novos modelos moleculares estão a informação de como as plantas são utilizadas por diferentes grupos étnicos e o estudo farmacológico das preparações utilizadas, abordadas, respectivamente no âmbito da Etnobotânica e da Etnofarmacologia (Rates, 2001).

A busca de novos compostos antifúngicos a partir de plantas da flora latinoamericana, baseada principalmente no seu uso etnofarmacológico, é tema do projeto de pesquisa X.7 do CYTED (Ciencia y Tecnologia para el Desarrollo) "Proyecto Iberoamericano de Búsqueda y Desarrollo de Antifúngicos Naturales y Análogos (PIBEAFUN).

Com base nos objetivos traçados pelo Projeto X.7 do CYTED (2002), este trabalho teve como finalidade a elaboração, a partir da literatura etnobotânica, de uma lista de plantas utilizadas na medicina popular brasileira no tratamento de sinais e sintomas relacionados a infecções fúngicas e verificar, para as 10 espécies mais citadas com essas finalidades, se já existem estudos para a avaliação da atividade antifúngica na base dados MEDLINE-PubMed.

\section{MATERIAL E MÉTODOS}

A busca bibliográfica foi feita em obras publicadas a partir de 1840: Martius (1844), Oliveira (1854), Moreira (1862), (1871), Caminhoá (1877), Castro (1878), Oliveira (1883), Dutra (1887), D’Ávila (1910), Freise (1933), Orth (1937), Reitz (1950), Reitz (1954), Moreira Filho e Goltcher (1972), Cavalcante e Frikel (1973), Van den Berg (1982), Neto (1987), Santos et al. (1988), Di Stasi et al.(1989), Paciornik (1990), Agra (1996), Matos (1998), Simões et al.(1998), Lorenzi e Matos (2002).As obras mais antigas representam levantamentos originais realizados junto às comunidades da época em que foram publicadas. A partir de 1980, constituem-se de levantamentos bibliográficos e foram selecionadas por serem elaboradas por autores ligados ao meio acadêmico e científico nacional.

A seleção dos sinais e sintomas empregados na busca bibliográfica foi baseada nas manifestações clínicas de infecções fúngicas relatadas por Carvalhaes de Oliveira (1999), Lacaz et al.(1991) e Edman (1998). Os sinais e sintomas considerados são os apresentados na sexta coluna da Tabela 1.

A nomenclatura das espécies foi atualizada, de acordo como banco de dados "W3 TROPICOS" do "Missouri Botanical Garden" ou o banco do "The International Plant Names Index”. Para a descrição dos usos relatados, procurou-se manter, sempre que possível, a linguagem utilizada pelos autores.

As famílias e 10 espécies mais citadas foram submetidas à busca bibliográfica na base de dados MEDLINE-
PubMed. Os termos utilizados para esta pesquisa foram: o binômio científico com as palavras "antifungal", "antifungic", "antimycotic", "fungal infections" e "antimicrobial".

\section{RESULTADOS E DISCUSSÃO}

Foram encontradas 409 espécies vegetais utilizadas no tratamento de sinais e sintomas aqui considerados como relacionados às infecções fúngicas (Tabela I). Essas espécies estão distribuídas em 98 famílias, sendo que as duas famílias com maior número de representantes citados foram as famílias Fabaceae (no sentido amplo) com 30 citações, e a família Asteraceae com 29 citações. Este pode ser um resultado importante, visto que estas duas famílias seriam consideradas prioritárias em estudos posteriores de avaliação de atividade antifúngica. Porém, entre as 10 espécies com maior número de citações, a maioria não pertence a estas famílias. Além disso, como essas famílias são constituídas de grande número de representantes se comparadas com outras famílias do Reino Plantae (Judd et al., 1999), este resultado pode ser decorrente do maior acesso da população a essas plantas e não de uma real seleção. Estas famílias também são juntamente com a família Piperaceae as mais testadas para a atividade antifúngica em um programa de screening de plantas medicinais latinoamericanas. Porém, neste screening, foi observado que o maior número de resultados positivos concentra-se na família Piperaceae (CYTED, 2003). A família Fabaceae foi também citada por Gottlieb e Borin (2003) como uma das dez famílias mais citadas em levantamentos etnobotânicos publicados no Journal of Ethnopharmacology. Desta família, provêm, segundo Gottlieb e Borin, principalmente substâncias ativas em doenças infecciosas e parasitárias. De fato, entre as duas famílias com maior número de representantes citados e, também, entre as famílias as quais pertencem as 10 espécies mais citadas, encontramos que o maior número de publicações é para a família Fabaceae (502), seguida por Asteraceae (108) e Lamiaceae (108). Para Anacardiaceae foram encontradas 17 citações; para Phytolacaceae e Bignoniaceae, 08; para Nyctaginaceae, 04. Não foram encontrados trabalhos com Cecropiaceae e Violaceae. A busca para a família Piperaceae resultou em 14 artigos.

As 10 espécies com maior número de citações estão relacionadas na Tabela 2. Observa-se que para 6 das 10 espécies com maior número de citações no levantamento bibliográfico não foram encontrados estudos de avaliação da atividade antifúngica. Além disso, o número de trabalhos científicos publicados não corresponde ao número de citações de uso popular. 
TABELA I - Plantas utilizadas para o tratamento de sinais e sintomas indicativos de infecções fúngicas

\begin{tabular}{|c|c|c|c|c|c|c|}
\hline Família Vegetal & $\begin{array}{l}\text { Nome Científico } \\
\text { Válido }\end{array}$ & $\begin{array}{l}\text { Nome Científico } \\
\text { (Referência Original) }\end{array}$ & Nome Popular & $\begin{array}{l}\text { Parte Vegetal } \\
\text { Utilizada/Produto } \\
\text { Extrativo }\end{array}$ & Uso Popular & Referências \\
\hline Amaryllidaceae & Agave americana $\mathrm{L}$. & $\begin{array}{l}\text { Agave americana } \\
\text { Martius A. americana }\end{array}$ & Piteira & $\begin{array}{l}\text { Folhas } \\
\text { Suco das folhas ou } \\
\text { depois de fermentado }\end{array}$ & $\begin{array}{l}\text { Feridas } \\
\text { Úlceras }\end{array}$ & $\begin{array}{l}\text { Moreira, } 1862 \\
\text { Castro, } 1878\end{array}$ \\
\hline Anacardiaceae & $\begin{array}{l}\text { Anacardium } \\
\text { occidentale } \mathrm{L} \text {. }\end{array}$ & $\begin{array}{l}\text { Anacardium occidentale } \\
\text { L. }\end{array}$ & Caju, acaju, cacaju & $\begin{array}{l}\text { Pericarpo } \\
\text { Entrecasca } \\
\text { Sumo da castanha } \\
\text { Casca } \\
\text { Folhas } \\
\text { Casca }\end{array}$ & $\begin{array}{l}\text { Feridas } \\
\text { Úlceras } \\
\text { leucorréia, } \\
\text { impingem }\end{array}$ & $\begin{array}{l}\text { Di Stasi et al.,1989 } \\
\text { Lorenzi e Matos, } 2002 \\
\text { Moreira, } 1862 \\
\text { Reitz, } 1954 \\
\text { Di Stasi et al.,1989 } \\
\text { Guarim Neto, } 1987 \\
\text { Di Stasi et al.,1989 } \\
\text { Reitz, } 1954\end{array}$ \\
\hline \multirow[t]{2}{*}{ Anacardiaceae } & \multirow[t]{2}{*}{$\begin{array}{l}\text { Astronium } \\
\text { urundeuva } \\
\text { (Allemão) Engl. }\end{array}$} & $\begin{array}{l}\text { Astronium orundeúva } \\
\text { Engl. }\end{array}$ & \multirow[t]{2}{*}{$\begin{array}{l}\text { Aroeira, aroeira-do- } \\
\text { sertão, urundeúva }\end{array}$} & Folhas & $\begin{array}{l}\text { Anti-séptica } \\
\text { sobre úlceras }\end{array}$ & Freise, 1933 \\
\hline & & $\begin{array}{l}\text { Myracrodruon } \\
\text { urundeuva Allemão }\end{array}$ & & n.i. & $\begin{array}{l}\text { Úlceras } \\
\text { externas }\end{array}$ & Agra, 1996 \\
\hline Anacardiaceae & $\begin{array}{l}\text { Lithraea } \\
\text { brasiliensis March. }\end{array}$ & $\begin{array}{l}\text { Lithraea brasiliensis } \\
\text { March. }\end{array}$ & Aroeira & Folhas & Dermatose & Reitz, 1950 \\
\hline Anacardiaceae & $\begin{array}{l}\text { Lithraea molleoides } \\
\text { (Vell.) Engl. }\end{array}$ & $\begin{array}{l}\text { Lythraea molleoides } \\
\text { (Vell.) Engl. }\end{array}$ & $\begin{array}{l}\text { Aroeira-brava, } \\
\text { aroeira-branca }\end{array}$ & Folhas & $\begin{array}{l}\text { Anti-séptica } \\
\text { sobre úlceras }\end{array}$ & Freise, 1933 \\
\hline \multirow[t]{2}{*}{ Anacardiaceae } & \multirow[t]{2}{*}{ Mangifera indica L. } & Mangifera indica & \multirow[t]{2}{*}{ Mangueira, manga } & $\begin{array}{l}\text { Casca, principalmente } \\
\text { da raiz }\end{array}$ & Leucorréia & Oliveira, 1854 \\
\hline & & M. indica $\mathrm{L}$. & & $\begin{array}{l}\text { Casca, raiz, sementes, } \\
\text { folhas e frutos }\end{array}$ & & Reitz, 1950 \\
\hline \multirow[t]{3}{*}{ Anacardiaceae } & \multirow[t]{3}{*}{ Schinus molle $\mathrm{L}$. } & \multirow[t]{3}{*}{ Schinus molle L. } & \multirow{3}{*}{$\begin{array}{l}\text { Anacauíta, aroeira, } \\
\text { aroeira-mansa, } \\
\text { aroeirinha, aroeira- } \\
\text { de-folha-de-salso }\end{array}$} & Folhas & $\begin{array}{l}\text { Anti-séptica, } \\
\text { úlceras }\end{array}$ & Freise, 1933 \\
\hline & & & & $\begin{array}{l}\text { Casca, frutas, goma- } \\
\text { resina, folhas }\end{array}$ & Leucorréia & Reitz, 1954 \\
\hline & & & & $\begin{array}{l}\text { Folhas, casca, resina } \\
\text { Planta inteira }\end{array}$ & Anti-séptico & $\begin{array}{l}\text { Simões et al., } 1998 \\
\text { Lorenzi e Matos, } 2002\end{array}$ \\
\hline Anacardiaceae & $\begin{array}{l}\text { Schinus } \\
\text { terebinthifolius } \\
\text { Raddi }\end{array}$ & $\begin{array}{l}\text { Schinus antiarthriticus, } \\
\text { S. terebinthifolia Raddi }\end{array}$ & $\begin{array}{l}\text { Aguaraíba, aroeira, } \\
\text { aroeira-do-rio- } \\
\text { grande-do-sul }\end{array}$ & $\begin{array}{l}\text { Folhas, frutos } \\
\text { Folhas }\end{array}$ & $\begin{array}{l}\text { Feridas e } \\
\text { úlceras } \\
\text { Úlceras } \\
\text { atônicas } \\
\text { Anti-séptica } \\
\text { sobre úlceras }\end{array}$ & $\begin{array}{l}\text { Oliveira, 1854; } \\
\text { Lorenzi e Matos, } 2002 \\
\text { Moreira, } 1871 \\
\text { Freise, } 1933\end{array}$ \\
\hline Anacardiaceae & Spondias lutea L. & Spondias lutea L. & Cajá & Casca nova & Leucorréia & Freise, 1933 \\
\hline Anacardiaceae & $\begin{array}{l}\text { Spondias mombin } \\
\mathrm{L} .\end{array}$ & $\begin{array}{l}\text { Spondias venulosas } \\
\text { Martius }\end{array}$ & Acaya & Caroços contusos & Leucorréia & Moreira, 1862 \\
\hline Annonaceae & $\begin{array}{l}\text { Annona spinescens } \\
\text { Mart. }\end{array}$ & $\begin{array}{l}\text { Anona spinescens } \\
\text { A. spinescens Mart }\end{array}$ & $\begin{array}{l}\text { Araticum-do-rio, } \\
\text { ou do-alagadiço }\end{array}$ & Fruto & Úlceras & $\begin{array}{l}\text { Oliveira, } 1854 \\
\text { Moreira, } 1862\end{array}$ \\
\hline Annonaceae & $\begin{array}{l}\text { Annona squamosa } \\
\text { L. }\end{array}$ & Annona squamosa L. & $\begin{array}{l}\text { Anona, araticum, } \\
\text { fruta-do-conde }\end{array}$ & Folhas & $\begin{array}{l}\text { Furúnculos, } \\
\text { úlceras }\end{array}$ & Lorenzi e Matos, 2002 \\
\hline Apiaceae & $\begin{array}{l}\text { Eryngium pristis } \\
\text { Cham. \& Schltdl./ }\end{array}$ & $\begin{array}{l}\text { Cryngium lingua } \\
\text { tucaniEryngium pristis } \\
\text { Cham. \& Schltdl. }\end{array}$ & Língua-de-tucano & n.i. & Aftas & $\begin{array}{l}\text { Oliveira, } 1854 \\
\text { Orth, } 1937\end{array}$ \\
\hline Apiaceae & $\begin{array}{l}\text { Foeniculum } \\
\text { vulgare Mill. }\end{array}$ & $\begin{array}{l}\text { Foeniculum ufulgare } \\
\text { Mii }\end{array}$ & Funcho & Fruto, raiz & Anti-séptico & Reitz, 1950 \\
\hline Apocynaceae & $\begin{array}{l}\text { Geissospermum } \\
\text { vellosii Allemão }\end{array}$ & $\begin{array}{l}\text { Geissospermum vellosii } \\
\text { (All) }\end{array}$ & Pau-pereira & n.i. & Anti-séptico & Oliveira, 1883 \\
\hline Apocynaceae & $\begin{array}{l}\text { Himatanthus } \\
\text { phagedaenicus } \\
\text { (Mart.) Woodson }\end{array}$ & $\begin{array}{l}\text { Plumeria phagedaenica } \\
\text { P. phagedenica Martius } \\
\text { P. phagedenica Mart. }\end{array}$ & $\begin{array}{l}\text { Sucuyba, sucuuba, } \\
\text { sebuü-üva }\end{array}$ & $\begin{array}{l}\text { Suco do arbusto } \\
\text { Suco leitosoFolhas } \\
\text { frescas }\end{array}$ & $\begin{array}{l}\text { Úlceras sórdidas } \\
\text { Úlceras atônicas } \\
\text { Impigens }\end{array}$ & $\begin{array}{l}\text { Oliveira, } 1854 \\
\text { Moreira, } 1862 \\
\text { Freise, } 1933\end{array}$ \\
\hline Apocynaceae & $\begin{array}{l}\text { Tabernaemontana } \\
\text { markgrafiana } \\
\text { J.F.Macbr. }\end{array}$ & $\begin{array}{l}\text { Bonafousia longituba } \\
\text { Mgf. }\end{array}$ & - & Folhas & $\begin{array}{l}\text { Anti-séptica e } \\
\text { cicatrizante de } \\
\text { feridas }\end{array}$ & $\begin{array}{l}\text { Cavalcante e Frikel, } \\
1973\end{array}$ \\
\hline Apocynaceae & $\begin{array}{l}\text { Thevetia ahouai } \\
\text { (L.) A.DC. }\end{array}$ & Thevetia ahovai & - & Folhas, sementes & $\begin{array}{l}\text { Feridas de má } \\
\text { qualidade }\end{array}$ & Oliveira, 1854 \\
\hline
\end{tabular}


TABELA I - cont.

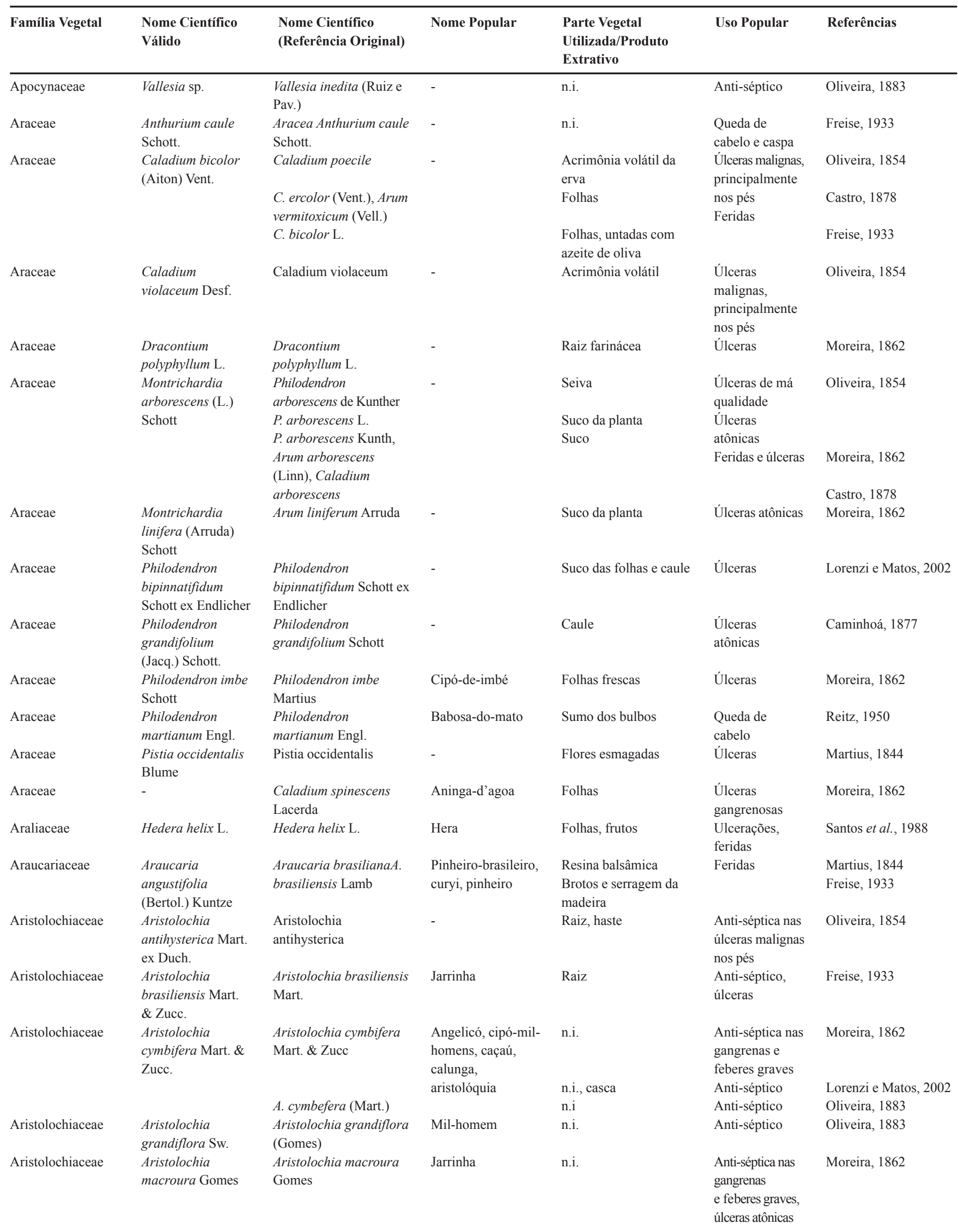


TABELA I - cont.

\begin{tabular}{|c|c|c|c|c|c|c|}
\hline Família Vegetal & $\begin{array}{l}\text { Nome Científico } \\
\text { Válido }\end{array}$ & $\begin{array}{l}\text { Nome Científico } \\
\text { (Referência Original) }\end{array}$ & Nome Popular & $\begin{array}{l}\text { Parte Vegetal } \\
\text { Utilizada/Produto } \\
\text { Extrativo }\end{array}$ & Uso Popular & Referências \\
\hline Aristolochiaceae & $\begin{array}{l}\text { Aristolochia } \\
\text { triangularis Cham. }\end{array}$ & $\begin{array}{l}\text { Aristolochia } \\
\text { triangularis Cham. et } \\
\text { Schl.A. triangularis } \\
\text { Cham. }\end{array}$ & $\begin{array}{l}\text { Cipó-mil-homens, } \\
\text { cipó-de-cobra, mil- } \\
\text { homens-do-rio- } \\
\text { grande, cipó-jarrinha }\end{array}$ & $\begin{array}{l}\text { Caule, raiz } \\
\text { Folhas, caules, raízes }\end{array}$ & $\begin{array}{l}\text { Manifestações } \\
\text { ulcerosasanti- } \\
\text { séptico }\end{array}$ & $\begin{array}{l}\text { Reitz, } 1950 \\
\text { Simões et al., } 1998\end{array}$ \\
\hline Aristolochiaceae & $\begin{array}{l}\text { Aristolochia } \\
\text { trilobata L. }\end{array}$ & $\begin{array}{l}\text { Aristolochia trilobata L. } \\
\text { A. trifida Lam., A. } \\
\text { caracasana Spreng., } \\
\text { Howardia trifida } \\
\text { Klotzsc }\end{array}$ & $\begin{array}{l}\text { Urubu-caá, } \\
\text { angelicó, calunga }\end{array}$ & $\begin{array}{l}\text { Raiz } \\
\text { Folhas }\end{array}$ & $\begin{array}{l}\text { Anti-séptico, } \\
\text { úlceras } \\
\text { crônicas }\end{array}$ & $\begin{array}{l}\text { Van den Berg, 1982; } \\
\text { Di Stasi, et al., } 1989 \\
\text { Van den Berg, } 1982\end{array}$ \\
\hline Asclepiadaceae & $\begin{array}{l}\text { Asclepias } \\
\text { curassavica } \mathrm{L} \text {. }\end{array}$ & $\begin{array}{l}\text { Asclepias curassavica } \\
\text { L. }\end{array}$ & Oficial-de-sala & Raiz & Leucorréia & Freise, 1933 \\
\hline Asteraceae & $\begin{array}{l}\text { Acanthospermum } \\
\text { australe (Loefl.) } \\
\text { Kuntze }\end{array}$ & $\begin{array}{l}\text { Acanthospermum } \\
\text { australe (Loefl.) Kuntze }\end{array}$ & $\begin{array}{l}\text { Amor-de-negro, } \\
\text { mata-pasto, picão- } \\
\text { da-praia }\end{array}$ & Folhas e raízes & $\begin{array}{l}\text { Úlceras, } \\
\text { feridas, } \\
\text { micoses }\end{array}$ & Lorenzi e Matos, 2002 \\
\hline Asteraceae & $\begin{array}{l}\text { Achyrocline } \\
\text { satureioides (Lam.) } \\
\text { DC. }\end{array}$ & $\begin{array}{l}\text { Achyrocline } \\
\text { satureioides (Lam.) DC. }\end{array}$ & Marcela, macela & Inflorescências & Anti-séptica & Simões et al., 1998 \\
\hline Asteraceae & $\begin{array}{l}\text { Ambrosia } \\
\text { artemisiifolia } \mathrm{L} .\end{array}$ & $\begin{array}{l}\text { Ambrosia artemisiifolia } \\
\text { L. }\end{array}$ & Ambrosia-americana & $\begin{array}{l}\text { Folhas, sumidades } \\
\text { floridas }\end{array}$ & Leucorréia & Reitz, 1954 \\
\hline Asteraceae & $\begin{array}{l}\text { Arctium minus } \\
\text { (Hill.) Bernh. }\end{array}$ & Lappa minor DC. & Bardana & Raízes, folhas & Dermopatias & D’Ávila, 1910 \\
\hline Asteraceae & Arnica montana $\mathrm{L}$. & $\begin{array}{l}\text { Arnica montana Linn. } \\
\text { A. montana } \mathrm{L} \text {. }\end{array}$ & Arnica & $\begin{array}{l}\text { Raiz } \\
\text { Capítulos florais }\end{array}$ & Anti-séptica & $\begin{array}{l}\text { Caminhoá, } 1877 \\
\text { Moreira Filho e } \\
\text { Goltcher, } 1972\end{array}$ \\
\hline Asteraceae & $\begin{array}{l}\text { Aster helenium (L.) } \\
\text { Scop. }\end{array}$ & Inula helenium Linn. & Enula & Raiz & Dartro & Caminhoá, 1877 \\
\hline Asteraceae & Bidens pilosa $\mathrm{L}$. & Bidens pilosus $\mathrm{L}$. & Picão & $\begin{array}{l}\text { Planta inteira } \\
\text { n.i. }\end{array}$ & $\begin{array}{l}\text { Úlceras } \\
\text { sórdidas } \\
\text { Úlceras }\end{array}$ & $\begin{array}{l}\text { Freise, } 1933 \\
\text { Orth, } 1937\end{array}$ \\
\hline Asteraceae & $\begin{array}{l}\text { Calendula } \\
\text { officinalis } \mathrm{L} .\end{array}$ & Calendula officinalis $\mathrm{L}$. & $\begin{array}{l}\text { Bonina, calêndula, } \\
\text { flor-de-todos-os- } \\
\text { males, malmequer }\end{array}$ & $\begin{array}{l}\text { Flores } \\
\text { Inflorescências }\end{array}$ & $\begin{array}{l}\text { Feridas } \\
\text { Anti-séptico, } \\
\text { feridas, úlceras, } \\
\text { micoses }\end{array}$ & $\begin{array}{l}\text { Santos et al., } 1988 \\
\text { Lorenzi e Matos, } 2002\end{array}$ \\
\hline Asteraceae & $\begin{array}{l}\text { Chaptalia nutans } \\
\text { (L.) Pol. }\end{array}$ & $\begin{array}{l}\text { Chaptalia nutans } \\
\text { Hemsley C. nutans } \\
\text { Hemse }\end{array}$ & Língua-de-vaca & $\begin{array}{l}\text { n.i. } \\
\text { Folhas }\end{array}$ & $\begin{array}{l}\text { Úlceras } \\
\text { diversas }\end{array}$ & $\begin{array}{l}\text { D'Ávila, } 1910 \\
\text { Orth, } 1937\end{array}$ \\
\hline Asteraceae & Conoclinium sp. & Conoclinium sp. & Caperiçoba & n.i. & Úlceras & Moreira, 1871 \\
\hline Asteraceae & Cynara scolymus L. & Cynara scolymus L. & Alcachofra & Folhas, raízes & Ácido úrico & Santos et al., 1988 \\
\hline Asteraceae & $\begin{array}{l}\text { Echinacea purpurea } \\
\text { (L.) Moench }\end{array}$ & $\begin{array}{l}\text { Echinacea purpurea } \\
\text { (L.) Moench }\end{array}$ & $\begin{array}{l}\text { Flor-roxa-cônica, } \\
\text { cometa-roxo }\end{array}$ & n.i. & $\begin{array}{l}\text { Antimicrobiano, } \\
\text { anti-séptico }\end{array}$ & Lorenzi e Matos, 2002 \\
\hline Asteraceae & $\begin{array}{l}\text { Elephantopus } \\
\text { mollis Kunth }\end{array}$ & $\begin{array}{l}\text { Elephantopus mollis } \\
\text { Kunth }\end{array}$ & $\begin{array}{l}\text { Erva-grossa, língua- } \\
\text { de-vaca, fumo- } \\
\text { bravo, erva-do-diabo }\end{array}$ & Folhas frescas & $\begin{array}{l}\text { Anti-séptico, } \\
\text { úlceras e } \\
\text { feridas, micoses }\end{array}$ & Lorenzi e Matos, 2002 \\
\hline Asteraceae & $\begin{array}{l}\text { Eupatorium } \\
\text { triplinerve Vahl }\end{array}$ & $\begin{array}{l}\text { Eupatorium triplinerve } \\
\text { Vahl. }\end{array}$ & Perna-de-saracura & Folhas & $\begin{array}{l}\text { Úlceras crônicas } \\
\text { e tórpidas }\end{array}$ & Freise, 1933 \\
\hline Asteraceae & $\begin{array}{l}\text { Galinsoga } \\
\text { parviflora } \mathrm{Cav} .\end{array}$ & $\begin{array}{l}\text { Galinsoga parviflora } \\
\text { Cav. }\end{array}$ & $\begin{array}{l}\text { Picão-branco, botão- } \\
\text { de-couro, fazendeiro }\end{array}$ & $\begin{array}{l}\text { n.i. } \\
\text { Folhas }\end{array}$ & Feridas & $\begin{array}{l}\text { Orth, } 1937 \\
\text { Lorenzi e Matos, } 2002\end{array}$ \\
\hline
\end{tabular}


TABELA I - cont.

\begin{tabular}{|c|c|c|c|c|c|c|}
\hline Família Vegetal & $\begin{array}{l}\text { Nome Científico } \\
\text { Válido }\end{array}$ & $\begin{array}{l}\text { Nome Científico } \\
\text { (Referência Original) }\end{array}$ & Nome Popular & $\begin{array}{l}\text { Parte Vegetal } \\
\text { Utilizada/Produto } \\
\text { Extrativo }\end{array}$ & Uso Popular & Referências \\
\hline Asteraceae & $\begin{array}{l}\text { Matricaria } \\
\text { chamomilla } \mathrm{L} .\end{array}$ & $\begin{array}{l}\text { Matricaria chamomilla } \\
\text { L. }\end{array}$ & Camomila & Capítulos florais & $\begin{array}{l}\text { Dermatites, } \\
\text { feridas banais }\end{array}$ & Santos et al., 1988 \\
\hline Asteraceae & $\begin{array}{l}\text { Mikania lindleyana } \\
\text { DC. }\end{array}$ & Mikania lindleyana DC. & Sucuriju & Folha & $\begin{array}{l}\text { Úlceras } \\
\text { crônicas }\end{array}$ & Van den Berg, 1982 \\
\hline Asteraceae & $\begin{array}{l}\text { Mikania parviflora } \\
\text { (Aubl.) H.Karst. }\end{array}$ & Mikania amara Willd. & Guaco & Planta inteira & $\begin{array}{l}\text { Feridas e } \\
\text { úlceras }\end{array}$ & Freise, 1933 \\
\hline Asteraceae & $\begin{array}{l}\text { Spilanthes acmella } \\
\text { (L.) Murray }\end{array}$ & Spilanthes acmella Murr & Jambu & Folhas & Úlceras & Guarim Neto, 1987 \\
\hline Asteraceae & $\begin{array}{l}\text { Tanacetum } \\
\text { parthenium (L.) } \\
\text { Sch. Bip. }\end{array}$ & $\begin{array}{l}\text { Chrysanthemum } \\
\text { partenium (L.) Bernh. }\end{array}$ & $\begin{array}{l}\text { Artemísia, artimijo, } \\
\text { artimigem }\end{array}$ & Folhas, inflorescências & $\begin{array}{l}\text { Feridas, } \\
\text { furúnculos }\end{array}$ & Paciornik, 1990 \\
\hline Bignoniaceae & $\begin{array}{l}\text { Arrabidaea chica } \\
\text { (Humb. \& Bonpl.) } \\
\text { B.Verl. }\end{array}$ & $\begin{array}{l}\text { Bignonia chica } \\
\text { Arrabidaea chica } \\
\text { (Bonpl.) B.Verl. }\end{array}$ & $\begin{array}{l}\text { Crajirú, carajiru, } \\
\text { carajuru }\end{array}$ & $\begin{array}{l}\text { Folhas } \\
\text { Folhas frescas }\end{array}$ & $\begin{array}{l}\text { Impigens } \\
\text { Antimicrobiano, } \\
\text { micoses, feridas }\end{array}$ & $\begin{array}{l}\text { Oliveira, } 1854 \\
\text { Lorenzi e Matos, } 2002\end{array}$ \\
\hline Bignoniaceae & $\begin{array}{l}\text { Arrabidaea } \\
\text { inaequalis (DC. ex } \\
\text { Splitg.) K.Schum. }\end{array}$ & $\begin{array}{l}\text { Arabidaea inaequalis } \\
\text { (DC ex Splitg.) K.Schm. }\end{array}$ & - & Raiz, haste & Caspa & $\begin{array}{l}\text { Cavalcante e Frikel, } \\
1973\end{array}$ \\
\hline Bignoniaceae & $\begin{array}{l}\text { Cybistax } \\
\text { antisyphilitica } \\
\text { (Mart.) Mart. }\end{array}$ & $\begin{array}{l}\text { Cybistax antisyphilitica } \\
\text { Mart. }\end{array}$ & Ipé-branco & Folhas & Dartros, úlceras & Reitz, 1954 \\
\hline Bignoniaceae & $\begin{array}{l}\text { Jacaranda caroba } \\
\text { (Vell.) A.DC. }\end{array}$ & $\begin{array}{l}\text { Jacaranda caroba } \\
\text { (Vell.) }\end{array}$ & Caroba & Folhas & Impigens & Castro, 1878 \\
\hline Bignoniaceae & $\begin{array}{l}\text { Jacaranda } \\
\text { oxyphylla Cham. }\end{array}$ & $\begin{array}{l}\text { Jacaranda oxyphylla } \\
\text { Cham. }\end{array}$ & Caroba & $\begin{array}{l}\text { Folhas } \\
\text { n.i. }\end{array}$ & Impingens & $\begin{array}{l}\text { Castro, } 1878 \\
\text { Martius, } 1844\end{array}$ \\
\hline Bignoniaceae & $\begin{array}{l}\text { Jacaranda } \\
\text { paucifolialata } \\
\text { Mart. ex A.DC. }\end{array}$ & $\begin{array}{l}\text { Jacaranda } \\
\text { paucifolialata Mart }\end{array}$ & Caroba & n.i. & Impingens & Orth, 1937 \\
\hline Bignoniaceae & $\begin{array}{l}\text { Jacaranda } \\
\text { puberula Cham. }\end{array}$ & $\begin{array}{l}\text { Jacaranda paulistana } \\
\text { Manso, Jacaranda } \\
\text { subrhombea (DC.), } \\
\text { Bignonia obovata } \\
\text { (Vell.) }\end{array}$ & Caroba & Folhas & Impingens & Castro, 1878 \\
\hline Bignoniaceae & $\begin{array}{l}\text { Jacaranda rufa } \\
\text { Silva Manso }\end{array}$ & Jacaranda rufa Manso & Caroba & Folhas & Impingens & Castro, 1878 \\
\hline Bignoniaceae & $\begin{array}{l}\text { Tabebuia } \\
\text { chrysantha (Jacq.) } \\
\text { G.Nicholson }\end{array}$ & Bignonia chrysanta DC. & Ipê & Casca & Dartro & Moreira, 1862 \\
\hline Bignoniaceae & $\begin{array}{l}\text { Tabebuia } \\
\text { heptaphylla (Vell.) } \\
\text { Toledo }\end{array}$ & $\begin{array}{l}\text { Tecoma ipe } \\
\text { T. ipe Mart. } \\
\text { Tabebuia avellanedae } \\
\text { Lor. ex Griseb }\end{array}$ & $\begin{array}{l}\text { Ipê-cavatã, ipê- } \\
\text { comum, ipê-preto, } \\
\text { ipê-rosa, ipê-roxo }\end{array}$ & $\begin{array}{l}\text { Casca } \\
\text { Cortice e folhas } \\
\text { Casca } \\
\text { Casca }\end{array}$ & $\begin{array}{l}\text { Impingem } \\
\text { Dartro } \\
\text { Antifúngico }\end{array}$ & $\begin{array}{l}\text { Oliveira, } 1854 \\
\text { D'Ávila, } 1910 \\
\text { Moreira, } 1862 \\
\text { Lorenzi e Matos, } 2002\end{array}$ \\
\hline Bignoniaceae & $\begin{array}{l}\text { Tabebuia } \\
\text { impetiginosa (Mart. } \\
\text { ex DC.) Standl. }\end{array}$ & Tecoma impetiginosa & $\begin{array}{l}\text { Ipê-contra-sarnas, } \\
\text { piauhy }\end{array}$ & $\begin{array}{l}\text { Casca } \\
\text { n.i. }\end{array}$ & $\begin{array}{l}\text { Dartros, } \\
\text { leucorréia }\end{array}$ & $\begin{array}{l}\text { Oliveira, } 1854 \\
\text { Moreira, } 1862\end{array}$ \\
\hline
\end{tabular}


TABELA I - cont.

\begin{tabular}{|c|c|c|c|c|c|c|}
\hline Família Vegetal & $\begin{array}{l}\text { Nome Científico } \\
\text { Válido }\end{array}$ & $\begin{array}{l}\text { Nome Científico } \\
\text { (Referência Original) }\end{array}$ & Nome Popular & $\begin{array}{l}\text { Parte Vegetal } \\
\text { Utilizada/Produto } \\
\text { Extrativo }\end{array}$ & Uso Popular & Referências \\
\hline Bignoniaceae & $\begin{array}{l}\text { Tabebuia vellosoi } \\
\text { Toledo }\end{array}$ & $\begin{array}{l}\text { Bignonia longiflora } \\
\text { Vell. }\end{array}$ & Ipê & Casca & Dartro & Moreira, 1862 \\
\hline Bignoniaceae & Tecoma sp. & Tecoma sp. & - & Córtice & Impigens & Orth, 1937 \\
\hline \multirow[t]{2}{*}{ Boraginaceae } & \multirow[t]{2}{*}{$\begin{array}{l}\text { Heliotropium } \\
\text { indicum L. }\end{array}$} & \multirow{2}{*}{$\begin{array}{l}\text { Tiaridium indicum, } \\
\text { Heliotropium indicum } \\
\text { H. indicum L. }\end{array}$} & \multirow{2}{*}{$\begin{array}{l}\text { Aguaraciunha, } \\
\text { macelinha, } \\
\text { borragem }\end{array}$} & n.i. & Úlceras & $\begin{array}{l}\text { Oliveira, 1854; } \\
\text { Moreira, } 1862\end{array}$ \\
\hline & & & & $\begin{array}{l}\text { Decocto } \\
\text { n.i. }\end{array}$ & Dartro & $\begin{array}{l}\text { Lorenzi e Matos, } 2002 \\
\text { Moreira, } 1862\end{array}$ \\
\hline Boraginaceae & $\begin{array}{l}\text { Patagonula } \\
\text { americana } \mathrm{L} \text {. }\end{array}$ & $\begin{array}{l}\text { Patagonula americana } \\
\text { L. }\end{array}$ & $\begin{array}{l}\text { Guajuvira, pau- } \\
\text { d'arco }\end{array}$ & Folhas & $\begin{array}{l}\text { Feridas, } \\
\text { ulcerações }\end{array}$ & Simões et al., 1998 \\
\hline Boraginaceae & $\begin{array}{l}\text { Symphytum } \\
\text { officinale L. }\end{array}$ & $\begin{array}{l}\text { Synphytum officinale } \mathrm{L} . \\
\text { Symphytum officinale } \mathrm{L} \text {. }\end{array}$ & Consólida, confrei & $\begin{array}{l}\text { Folhas } \\
\text { Raízes, folhas }\end{array}$ & Feridas & $\begin{array}{l}\text { Paciornik, } 1990 \\
\text { Simões et al., } 1998\end{array}$ \\
\hline Burseraceae & $\begin{array}{l}\text { Protium brasiliense } \\
\text { (Spreng.) Engl. }\end{array}$ & $\begin{array}{l}\text { Protium brasiliense } \\
\text { Engl. }\end{array}$ & Almécega & $\begin{array}{l}\text { Óleo-resina extraído do } \\
\text { tronco }\end{array}$ & $\begin{array}{l}\text { Úlceras } \\
\text { gangrenosas }\end{array}$ & Reitz, 1950 \\
\hline Burseraceae & $\begin{array}{l}\text { Protium } \\
\text { heptaphyllum } \\
\text { (Aubl.) March. }\end{array}$ & $\begin{array}{l}\text { Protium heptaphyllum } \\
\text { (Aublet) Marchand }\end{array}$ & Almécega & $\begin{array}{l}\text { Óleo-resina extraído do } \\
\text { tronco }\end{array}$ & $\begin{array}{l}\text { Úlceras } \\
\text { gangrenosas }\end{array}$ & Reitz, 1950 \\
\hline Burseraceae & $\begin{array}{l}\text { Protium icicariba } \\
\text { (DC.) March. }\end{array}$ & $\begin{array}{l}\text { Protium icicariba (De } \\
\text { Candole) Marchand }{ }^{1}\end{array}$ & Almécega & $\begin{array}{l}\text { Óleo-resina extraído do } \\
\text { tronco }\end{array}$ & $\begin{array}{l}\text { Úlceras } \\
\text { gangrenosas }\end{array}$ & Reitz, 1950 \\
\hline Cactaceae & $\begin{array}{l}\text { Cereus stellatus } \\
\text { Pfeiff. }\end{array}$ & Ceri varii stantes & Jamaracú & Raminhos contusos & $\begin{array}{l}\text { Úlceras } \\
\text { fagedências }\end{array}$ & Oliveira, 1854 \\
\hline Cactaceae & $\begin{array}{l}\text { Cereus variabilis } \\
\text { Pfeiff. }\end{array}$ & Cereus variabilis Pfeiff. & Cumbeba & Fruto & $\begin{array}{l}\text { Úlceras } \\
\text { sórdidas }\end{array}$ & Moreira, 1862 \\
\hline Cannaceae & Canna glauca $\mathrm{L}$. & $\begin{array}{l}\text { Canna glauca, Canna } \\
\text { angustifolia }\end{array}$ & Albará & $\begin{array}{l}\text { Raízes e radículas } \\
\text { Planta fresca }\end{array}$ & $\begin{array}{l}\text { Feridas } \\
\text { Úlceras }\end{array}$ & $\begin{array}{l}\text { Martius, } 1844 \\
\text { Oliveira, } 1854\end{array}$ \\
\hline Cannaceae & Canna indica $\mathrm{L}$. & $\begin{array}{l}\text { Canna edulis e Canna } \\
\text { indica Velloso }\end{array}$ & Caeté-dos-jardins & Planta fresca & Úlceras & Oliveira, 1854 \\
\hline Caprifoliaceae & $\begin{array}{l}\text { Lonicera japonica } \\
\text { Thunb. ex Murray }\end{array}$ & $\begin{array}{l}\text { Lonicera japonica } \\
\text { Thunb. ex Murray }\end{array}$ & $\begin{array}{l}\text { Madressilva, } \\
\text { madressilva-do- } \\
\text { japão, maravilha }\end{array}$ & Folhas, flores & Anti-séptico & Lorenzi e Matos, 2002 \\
\hline Caprifoliaceae & Sambucus nigra L. & Sambucus nigra $\mathrm{L}$. & Sabugueiro & Flores & $\begin{array}{l}\text { Dermatoses e } \\
\text { furúnculos }\end{array}$ & Simões et al., 1998 \\
\hline Caricaceae & Carica papaya $\mathrm{L}$. & Carica papaya $\mathrm{L}$. & Mamoeira, mamão & $\begin{array}{l}\text { Frutos verdes } \\
\text { Sementes, folhas, } \\
\text { fruto, tronco }\end{array}$ & $\begin{array}{l}\text { Úlceras } \\
\text { Úlceras } \\
\text { crônicas }\end{array}$ & $\begin{array}{l}\text { Moreira, } 1862 \\
\text { Van den Berg, } 1982\end{array}$ \\
\hline Caricaceae & $\begin{array}{l}\text { Jacaratia digitata } \\
\text { (Poepp. \& Endl.) } \\
\text { Solms }\end{array}$ & Carica digitata & Jaracatiá & Fruto & Feridas, úlceras & Oliveira, 1854 \\
\hline Caricaceae & $\begin{array}{l}\text { Jacaratia spinosa } \\
\text { (Aubl.) A.DC. }\end{array}$ & Carica dodecaphylla & Jaracatiá & Fruto & Feridas, úlceras & Oliveira, 1854 \\
\hline Cecropiaceae & $\begin{array}{l}\text { Cecropia } \\
\text { catarinensis } \\
\text { Cuatrec. }\end{array}$ & $\begin{array}{l}\text { Cecropia catarinensis } \\
\text { Cuatrecosas }\end{array}$ & $\begin{array}{l}\text { Embaúba, baúna, } \\
\text { árvore-da-preguiça }\end{array}$ & Folhas & Corrimento & Simões et al., 1998 \\
\hline
\end{tabular}


TABELA I - cont.

\begin{tabular}{|c|c|c|c|c|c|c|}
\hline Família Vegetal & $\begin{array}{l}\text { Nome Científico } \\
\text { Válido }\end{array}$ & $\begin{array}{l}\text { Nome Científico } \\
\text { (Referência Original) }\end{array}$ & Nome Popular & $\begin{array}{l}\text { Parte Vegetal } \\
\text { Utilizada/Produto } \\
\text { Extrativo }\end{array}$ & Uso Popular & Referências \\
\hline \multirow[t]{3}{*}{ Cecropiaceae } & \multirow[t]{3}{*}{ Cecropia peltata $\mathrm{L}$. } & C. peltata & \multirow{3}{*}{$\begin{array}{l}\text { Umbaúba, } \\
\text { imbahiba, ambaiba, } \\
\text { árvore-da- } \\
\text { preguiça, imbaúba, } \\
\text { ambaitinga }\end{array}$} & $\begin{array}{l}\text { Suco das } \\
\text { castanhasSuco das } \\
\text { castanhas com leite }\end{array}$ & Leucorréia & $\begin{array}{l}\text { Moreira, 1862; } \\
\text { Moreira, } 1871\end{array}$ \\
\hline & & Cecropia peltata (Weld) & & $\begin{array}{l}\text { Massa do interior do } \\
\text { tronco }\end{array}$ & Úlceras & Oliveira, 1883 \\
\hline & & C. peltata $\mathrm{L}$. & & $\begin{array}{l}\text { Látex } \\
\text { Flores brancas ("suco } \\
\text { dos olhos" ou gomos) }\end{array}$ & $\begin{array}{l}\text { Úlceras } \\
\text { gangrenosas }\end{array}$ & $\begin{array}{l}\text { Moreira, } 1862 \\
\text { Di Stasi et al., } 1989 \\
\text { Oliveira, } 1854\end{array}$ \\
\hline Cecropiaceae & Cecropia sp. & Cecropia sp. & $\begin{array}{l}\text { Embaúba, } \\
\text { embaúva }\end{array}$ & Suco dos brotos & $\begin{array}{l}\text { Leucorréia, } \\
\text { úlceras rebeldes } \\
\text { e torpes }\end{array}$ & Freise, 1933 \\
\hline Celastraceae & $\begin{array}{l}\text { Maytenus ilicifolia } \\
\text { Mart. ex Reissek }\end{array}$ & $\begin{array}{l}\text { Maytenus ilicifolia } \\
\text { Mart. }\end{array}$ & $\begin{array}{l}\text { Concorosa, } \\
\text { sombra-de-touro, } \\
\text { espinheira-santa, } \\
\text { concerosa }\end{array}$ & $\begin{array}{l}\text { Folhas } \\
\text { Folhas }\end{array}$ & $\begin{array}{l}\text { Feridas, úlceras } \\
\text { Anti-séptica em } \\
\text { feridas e úlceras }\end{array}$ & Simões et al., 1998 \\
\hline Celastraceae & $\begin{array}{l}\text { Maytenus rigida } \\
\text { Mart. }\end{array}$ & Maytenus rigida Mart. & $\begin{array}{l}\text { Bom-nome, pau- } \\
\text { de-colher, bom- } \\
\text { homem }\end{array}$ & n.i. & $\begin{array}{l}\text { Úlceras } \\
\text { externas e } \\
\text { vaginais }\end{array}$ & Agra, 1996 \\
\hline \multirow[t]{2}{*}{ Chenopodiaceae } & \multirow[t]{2}{*}{$\begin{array}{l}\text { Chenopodium } \\
\text { ambrosioides } \mathrm{L} .\end{array}$} & $\begin{array}{l}\text { Chenopodium } \\
\text { ambrosioides Bert. }\end{array}$ & $\begin{array}{l}\text { Mastruz, erva-de- } \\
\text { santa-maria, }\end{array}$ & Folhas & $\begin{array}{l}\text { Corrimento } \\
\text { vaginal }\end{array}$ & Di Stasi et al.,1989 \\
\hline & & C.ambrosioides $\mathrm{L}$. & $\begin{array}{l}\text { ambrosia, erva-de- } \\
\text { bicho, mastruço, } \\
\text { menstrus }\end{array}$ & $\begin{array}{l}\text { Folhas, sementes ou } \\
\text { partes aéreas }\end{array}$ & $\begin{array}{l}\text { Anti-séptico } \\
\text { local }\end{array}$ & Matos, 1998 \\
\hline Chrysobalanaceae & $\begin{array}{l}\text { Chrysobalanus } \\
\text { icaco L. }\end{array}$ & $\begin{array}{l}\text { Chrysobalanus icaco } \\
\text { C. icaco L. }\end{array}$ & Goajuru & $\begin{array}{l}\text { Raiz, casca, folhas } \\
\text { Folhas, raiz } \\
\text { Toda planta }\end{array}$ & Leucorréia & $\begin{array}{l}\text { Oliveira, } 1854 \\
\text { Moreira, } 1862 \\
\text { Freise, } 1933\end{array}$ \\
\hline Clusiaceae & $\begin{array}{l}\text { Caraipa densifolia } \\
\text { Mart. }\end{array}$ & $\begin{array}{l}\text { Caraipa densifolia } \\
\text { Mart.,Caraipa laxiflora } \\
\text { Benth. }\end{array}$ & $\begin{array}{l}\text { Macucu, tamcoaré, } \\
\text { tamancoaré-branco }\end{array}$ & Casca & $\begin{array}{l}\text { Dermatoses, } \\
\text { impingem, } \\
\text { dartros }\end{array}$ & Van den Berg, 1982 \\
\hline Clusiaceae & $\begin{array}{l}\text { Caraipa excelsa } \\
\text { Ducke }\end{array}$ & Caraipa excelsa Ducke & $\begin{array}{l}\text { Macucu, tamcoaré, } \\
\text { tamancoaré-branco }\end{array}$ & Casca & $\begin{array}{l}\text { Dermatoses, } \\
\text { impingem, } \\
\text { dartros }\end{array}$ & Van den Berg, 1982 \\
\hline Clusiaceae & $\begin{array}{l}\text { Caraipa fasciculata } \\
\text { Cambess. }\end{array}$ & $\begin{array}{l}\text { Caraipa fasciculata } \\
\text { Camb. }\end{array}$ & $\begin{array}{l}\text { Macucu, tamcoaré, } \\
\text { tamancoaré-branco }\end{array}$ & Casca & $\begin{array}{l}\text { Dermatoses, } \\
\text { impingem, } \\
\text { dartros }\end{array}$ & Van den Berg, 1982 \\
\hline Clusiaceae & $\begin{array}{l}\text { Caraipa lacerdaei } \\
\text { Barb. Rodr. }\end{array}$ & $\begin{array}{l}\text { Caraipa lacerdaei Barb. } \\
\text { Rodr. }\end{array}$ & $\begin{array}{l}\text { Tamaquaré, } \\
\text { tamaquary }\end{array}$ & $\begin{array}{l}\text { Óleo obtido por } \\
\text { incisões no tronco }\end{array}$ & Dartros & Freise, 1933 \\
\hline Clusiaceae & $\begin{array}{l}\text { Caraipa laxiflora } \\
\text { Benth. }\end{array}$ & $\begin{array}{l}\text { Caraipa laxiflora } \\
\text { Benth. }\end{array}$ & $\begin{array}{l}\text { Macucu, tamcoaré, } \\
\text { tamancoaré-branco }\end{array}$ & Casca & $\begin{array}{l}\text { Dermatoses, } \\
\text { impingem, } \\
\text { dartros }\end{array}$ & Van den Berg, 1982 \\
\hline Clusiaceae & $\begin{array}{l}\text { Caraipa } \\
\text { melhemiana Paula }\end{array}$ & $\begin{array}{l}\text { Caraipa melhemiana } \\
\text { Paula }\end{array}$ & $\begin{array}{l}\text { Macucu, tamcoaré, } \\
\text { tamancoaré-branco }\end{array}$ & Casca & $\begin{array}{l}\text { Dermatoses, } \\
\text { impingem, } \\
\text { dartros }\end{array}$ & Van den Berg, 1982 \\
\hline Clusiaceae & $\begin{array}{l}\text { Caraipa minor } \\
\text { Huber }\end{array}$ & Caraipa minor Hub. & $\begin{array}{l}\text { Tamaquaré, } \\
\text { tamaquary }\end{array}$ & $\begin{array}{l}\text { Óleo obtido por } \\
\text { incisões no tronco }\end{array}$ & Dartros & Freise, 1933 \\
\hline Clusiaceae & $\begin{array}{l}\text { Caraipa palustris } \\
\text { Barb. Rodr. }\end{array}$ & $\begin{array}{l}\text { Caraipa palustris Barb. } \\
\text { Rodr. }\end{array}$ & $\begin{array}{l}\text { Tamaquaré, } \\
\text { tamaquary }\end{array}$ & $\begin{array}{l}\text { Óleo obtido por } \\
\text { incisões no tronco }\end{array}$ & Dartros & Freise, 1933 \\
\hline Clusiaceae & $\begin{array}{l}\text { Caraipa psidiifolia } \\
\text { Ducke }\end{array}$ & $\begin{array}{l}\text { Caraipa psidifolia } \\
\text { Ducke }\end{array}$ & $\begin{array}{l}\text { Tamaquaré, } \\
\text { tamaquary }\end{array}$ & $\begin{array}{l}\text { Óleo obtido por } \\
\text { incisões no tronco }\end{array}$ & Dartros & Freise, 1933 \\
\hline Clusiaceae & $\begin{array}{l}\text { Caraipa variabilis } \\
\text { Cambess. }\end{array}$ & $\begin{array}{l}\text { Caraipa variabilis } \\
\text { Camb. }\end{array}$ & $\begin{array}{l}\text { Macucu, tamcoaré, } \\
\text { tamancoaré-branco }\end{array}$ & Casca & $\begin{array}{l}\text { Dermatoses, } \\
\text { impingem, } \\
\text { dartros }\end{array}$ & Van den Berg, 1982 \\
\hline Clusiaceae & $\begin{array}{l}\text { Clusia purpurea } \\
\text { (Splitg.) Engl. }\end{array}$ & $\begin{array}{l}\text { Clusia purpurea (Splitg) } \\
\text { Engl. }\end{array}$ & Cebola-brava & Entrecasca & $\begin{array}{l}\text { Anti-séptica e } \\
\text { cicatrizante de } \\
\text { feridas }\end{array}$ & $\begin{array}{l}\text { Cavalcante e Frikel, } \\
1973\end{array}$ \\
\hline Clusiaceae & $\begin{array}{l}\text { Hypericum } \\
\text { brasiliense Choisy }\end{array}$ & $\begin{array}{l}\text { Hypericum laxiusculum } \\
\text { A St. Hilaire }\end{array}$ & - & n.i & Feridas & Orth, 1937 \\
\hline & & & & & Aftas & Lorenzi e Matos, 2002 \\
\hline Clusiaceae & $\begin{array}{l}\text { Hypericum } \\
\text { connatum Lam. }\end{array}$ & $\begin{array}{l}\text { H. brasiliense Choisy } \\
\text { Hypericum connatum } \\
\text { Lam. }\end{array}$ & - & $\begin{array}{l}\text { Folhas } \\
\text { n.i. }\end{array}$ & Aftas & $\begin{array}{l}\text { D’Ávila, } 1910 \\
\text { Orth, 1937; } \\
\text { Lorenzi e Matos, } 2002\end{array}$ \\
\hline
\end{tabular}


TABELA I - cont.

\begin{tabular}{|c|c|c|c|c|c|c|}
\hline Família Vegetal & $\begin{array}{l}\text { Nome Científico } \\
\text { Válido }\end{array}$ & $\begin{array}{l}\text { Nome Científico } \\
\text { (Referência Original) }\end{array}$ & Nome Popular & $\begin{array}{l}\text { Parte Vegetal } \\
\text { Utilizada/Produto } \\
\text { Extrativo }\end{array}$ & Uso Popular & Referências \\
\hline Clusiaceae & $\begin{array}{l}\text { Hypericum } \\
\text { perforatum } \mathrm{L} \text {. }\end{array}$ & $\begin{array}{l}\text { Hypericum perforatum } \\
\text { L. }\end{array}$ & $\begin{array}{l}\text { alecrim-bravo, } \\
\text { erva-de-são-joão, } \\
\text { hipérico }\end{array}$ & Planta inteira & Anti-séptico & Lorenzi e Matos, 2002 \\
\hline Clusiaceae & $\begin{array}{l}\text { Mammea } \\
\text { americana } \mathrm{L} .\end{array}$ & $\begin{array}{l}\text { Mammea americana } \\
\text { M. americana } \mathrm{L} \text {. }\end{array}$ & $\begin{array}{l}\text { Abricó-do-pará, } \\
\text { abricó, abricoteiro }\end{array}$ & $\begin{array}{l}\text { n.i. } \\
\text { Suco leitoso da árvore }\end{array}$ & $\begin{array}{l}\text { Úlceras de má } \\
\text { qualidade } \\
\text { Dermatoses } \\
\text { Úlceras }\end{array}$ & $\begin{array}{l}\text { Oliveira, } 1854 \\
\text { Lorenzi e Matos, } 2002 \\
\text { Moreira, } 1862\end{array}$ \\
\hline Clusiaceae & $\begin{array}{l}\text { Vismia guianensis } \\
\text { (Aubl.) Choisy }\end{array}$ & $\begin{array}{l}\text { Vismia guianensis } \\
\text { (Aubl.), Hypericum } \\
\text { guianense Aubl. } \\
\text { V. guianensis (Aubl.) } \\
\text { Choisy }\end{array}$ & $\begin{array}{l}\text { Lacre, lacre- } \\
\text { branco, caó-opiá, } \\
\text { caopiá }\end{array}$ & Goma-resina & $\begin{array}{l}\text { Diversas } \\
\text { dermatoses, } \\
\text { principalmente } \\
\text { impingens } \\
\text { Micoses, } \\
\text { impingem }\end{array}$ & Lorenzi e Matos, 2002 \\
\hline Clusiaceae & $\begin{array}{l}\text { Vismia japurensis } \\
\text { Reichardt }\end{array}$ & $\begin{array}{l}\text { Vismia japurensis } \\
\text { Reich., Caopia }\end{array}$ & $\begin{array}{l}\text { Lacrão, pau-de- } \\
\text { lacre }\end{array}$ & Casca & Dermatoses & Van den Berg, 1982 \\
\hline Combretaceae & $\begin{array}{l}\text { Terminalia } \\
\text { argentea (Camb.) } \\
\text { Mart. }\end{array}$ & $\begin{array}{l}\text { japurensis Kuntze } \\
\text { Terminalia argentea } \\
\text { Mart. \& Zucc. }\end{array}$ & Pau-de-bicho & Casca & Aftas & Guarim Neto, 1987 \\
\hline Commelinaceae & $\begin{array}{l}\text { Commelina } \\
\text { deficiens Hook. }\end{array}$ & $\begin{array}{l}\text { Commelina deficiens } \\
\text { Hook. }\end{array}$ & Marianinha & n.i. & $\begin{array}{l}\text { Dartros, } \\
\text { leucorréia }\end{array}$ & Moreira, 1862 \\
\hline Commelinaceae & $\begin{array}{l}\text { Dichorisandra } \\
\text { affinis Mart. }\end{array}$ & $\begin{array}{l}\text { Dichorisandra affins } \\
\text { Mart. }\end{array}$ & Disciplina & Folha & Dartros & Van den Berg, 1982 \\
\hline Commelinaceae & $\begin{array}{l}\text { Tripogandra } \\
\text { diuretica (Mart.) } \\
\text { Handlos }\end{array}$ & $\begin{array}{l}\text { Tradescantia diuretica } \\
\text { Martius }\end{array}$ & Tropoeraba & Folhas frescas & $\begin{array}{l}\text { Dartros, } \\
\text { leucorréia }\end{array}$ & Moreira, 1862 \\
\hline Convolvulaceae & $\begin{array}{l}\text { Cuscuta platyloba } \\
\text { Progel }\end{array}$ & $\begin{array}{l}\text { Cuscuta platyloba } \\
\text { Progel }\end{array}$ & Cipó-chumbo & Planta inteira & Úlceras & Reitz, 1954 \\
\hline Convolvulaceae & $\begin{array}{l}\text { Cuscuta umbellata } \\
\text { Kunth }\end{array}$ & $\begin{array}{l}\text { Cuscuta umbellata, } C \text {. } \\
\text { racemosa C. umbellata } \\
\text { Humboldt, C. racemosa } \\
\text { Mart. C. umbellata } \\
\text { Humb }\end{array}$ & $\begin{array}{l}\text { Cipó-chumbo, } \\
\text { cipó-de-chumbo }\end{array}$ & $\begin{array}{l}\text { Planta seca } \\
\text { Suco } \\
\text { Planta inteira }\end{array}$ & $\begin{array}{l}\text { Feridas } \\
\text { recentes } \\
\text { Feridas }\end{array}$ & $\begin{array}{l}\text { Oliveira, } 1854 \\
\text { Moreira, } 1862 \\
\text { Freise, } 1933\end{array}$ \\
\hline Convolvulaceae & $\begin{array}{l}\text { Ipomoea pes- } \\
\text { caprae (L.) R.Br. }\end{array}$ & $\begin{array}{l}\text { Ipomoea pes-caprae } \\
\text { (L.) R.Br. }\end{array}$ & $\begin{array}{l}\text { Salsa-da-praia, } \\
\text { batata-da-praia, } \\
\text { ipoméia }\end{array}$ & Folhas & $\begin{array}{l}\text { Furúnculos, } \\
\text { feridas }\end{array}$ & Lorenzi e Matos, 2002 \\
\hline Crassulaceae & $\begin{array}{l}\text { Bryophyllum } \\
\text { pinnatum (Lam.) } \\
\text { Oken }\end{array}$ & $\begin{array}{l}\text { Bryophylum calycynum } \\
\text { Salisb.B. pinnatum } \\
\text { (Lam.) Oken }\end{array}$ & $\begin{array}{l}\text { Folha-da-fortuna, } \\
\text { courama, coirama, } \\
\text { fortuna }\end{array}$ & $\begin{array}{l}\text { Folhas } \\
\text { n.i. }\end{array}$ & Furúnculos & $\begin{array}{l}\text { Paciornik, } 1990 \\
\text { Lorenzi e Matos, } 2002\end{array}$ \\
\hline Crassulaceae & $\begin{array}{l}\text { Kalanchoe } \\
\text { brasiliensis Camb. }\end{array}$ & $\begin{array}{l}\text { Kalanchoes brasiliensis } \\
\text { Camb. }\end{array}$ & Saião & Suco das folhas & Feridas & Moreira, 1862 \\
\hline Cucurbitaceae & $\begin{array}{l}\text { Cayaponia } \\
\text { bonariensis (Mill.) } \\
\text { M. Crovetto }\end{array}$ & $\begin{array}{l}\text { Trianosperma ficifolia } \\
\text { Mart. T. ficifolia Cogn. }\end{array}$ & $\begin{array}{l}\text { Taiuá, abobrinha- } \\
\text { do-mato }\end{array}$ & $\begin{array}{l}\text { Folhas } \\
\text { Raiz }\end{array}$ & $\begin{array}{l}\text { Leucorragias } \\
\text { agudas e } \\
\text { crônicas }\end{array}$ & $\begin{array}{l}\text { D’Ávila, } 1910 \\
\text { Orth, } 1937\end{array}$ \\
\hline Cucurbitaceae & $\begin{array}{l}\text { Cayaponia tayuya } \\
\text { (Vell.) Cogn. }\end{array}$ & $\begin{array}{l}\text { Cayaponia tayuya } \\
\text { (Mart.) Cogn, } \\
\text { Trianosperma tayuya } \\
\text { Mart.C. tayuya (Vell.) } \\
\text { Cogn. }\end{array}$ & $\begin{array}{l}\text { Taiuiá, tajujá, } \\
\text { abobrinha-do-mato, } \\
\text { guardião }\end{array}$ & Raiz, folhas e frutos & $\begin{array}{l}\text { Úlceras, } \\
\text { furúnculos }\end{array}$ & Van den Berg, 1982 \\
\hline Cucurbitaceae & Curcubita pepo L. & Curcubita pepo L. & $\begin{array}{l}\text { Abóbora, abóbora- } \\
\text { amarela }\end{array}$ & n.i. & $\begin{array}{l}\text { Feridas, } \\
\text { corrimento } \\
\text { vaginal }\end{array}$ & Lorenzi e Matos, 2002 \\
\hline Cucurbitaceae & Fevillea trilobata $\mathrm{L}$. & Feuillea trilobata L. & Nhandiroba & Óleo das sementes & Impingens & Freise, 1933 \\
\hline Cucurbitaceae & $\begin{array}{l}\text { Momordica } \\
\text { charantia } \mathrm{L} .\end{array}$ & $\begin{array}{l}\text { Momordica charantea } \mathrm{L} \\
\text { M. charantia } \mathrm{L} .\end{array}$ & $\begin{array}{l}\text { Melão-de-são- } \\
\text { caetano, fruto-de- } \\
\text { cobra }\end{array}$ & $\begin{array}{l}\text { Folhas } \\
\text { Sumo das folhas }\end{array}$ & Leucorréia & $\begin{array}{l}\text { Moreira, } 1862 \\
\text { Di Stasi et al.,1989 }\end{array}$ \\
\hline Cupressaceae & $\begin{array}{l}\text { Juniperus } \\
\text { oxycedrus L. }\end{array}$ & Juniperus oxycedrus L. & Oxicedro & Madeira & $\begin{array}{l}\text { Dermatoses em } \\
\text { geral }\end{array}$ & $\begin{array}{l}\text { Moreira Filho e } \\
\text { Goltcher, } 1972\end{array}$ \\
\hline Cyperaceae & $\begin{array}{l}\text { Cyperus rotundus } \\
\text { L. }\end{array}$ & Cyperus rotundus $\mathrm{L}$. & $\begin{array}{l}\text { Tiririca, junçá- } \\
\text { aromática, alho }\end{array}$ & Tubérculo & Feridas & Lorenzi e Matos, 2002 \\
\hline
\end{tabular}


TABELA I - cont.

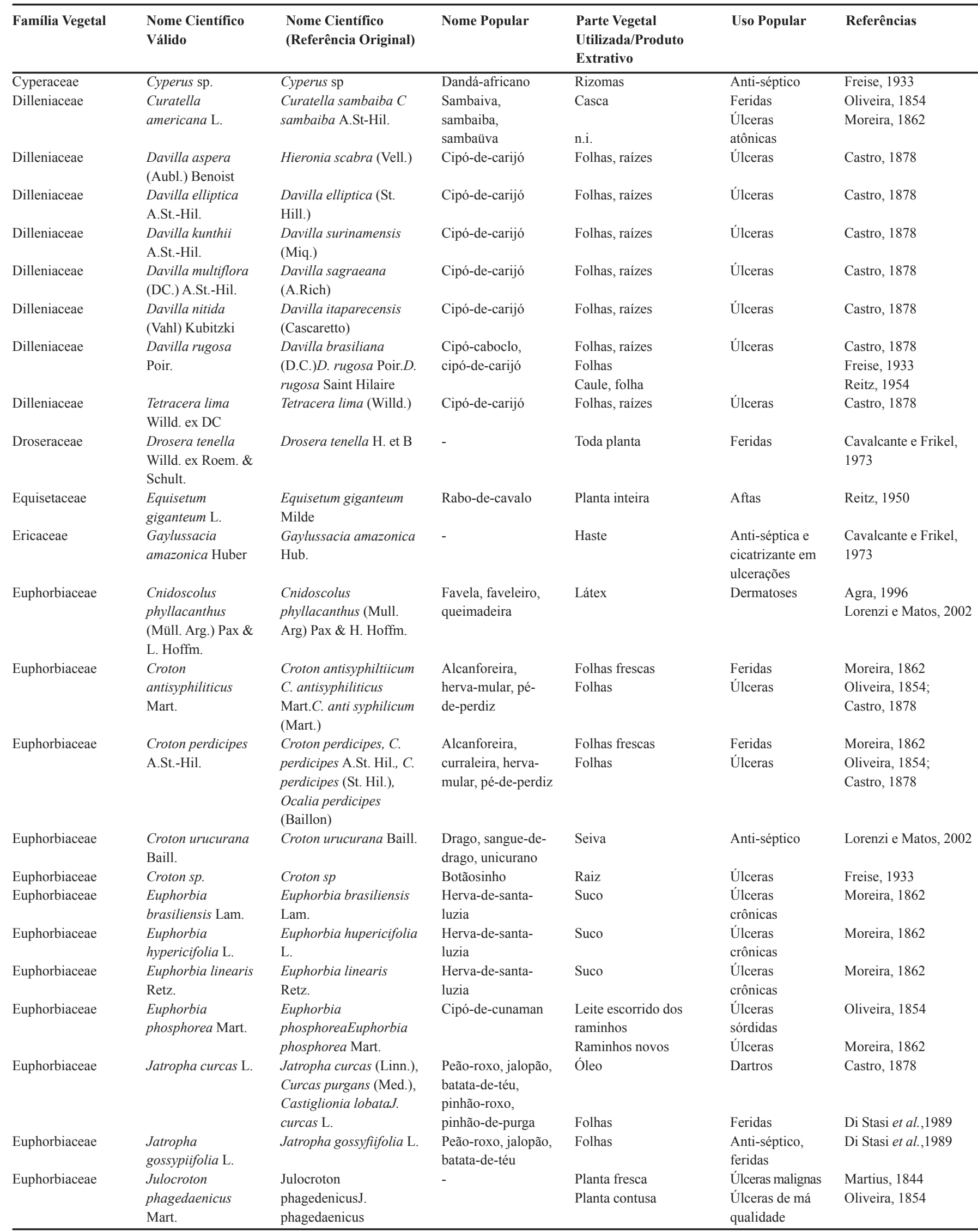


TABELA I - cont.

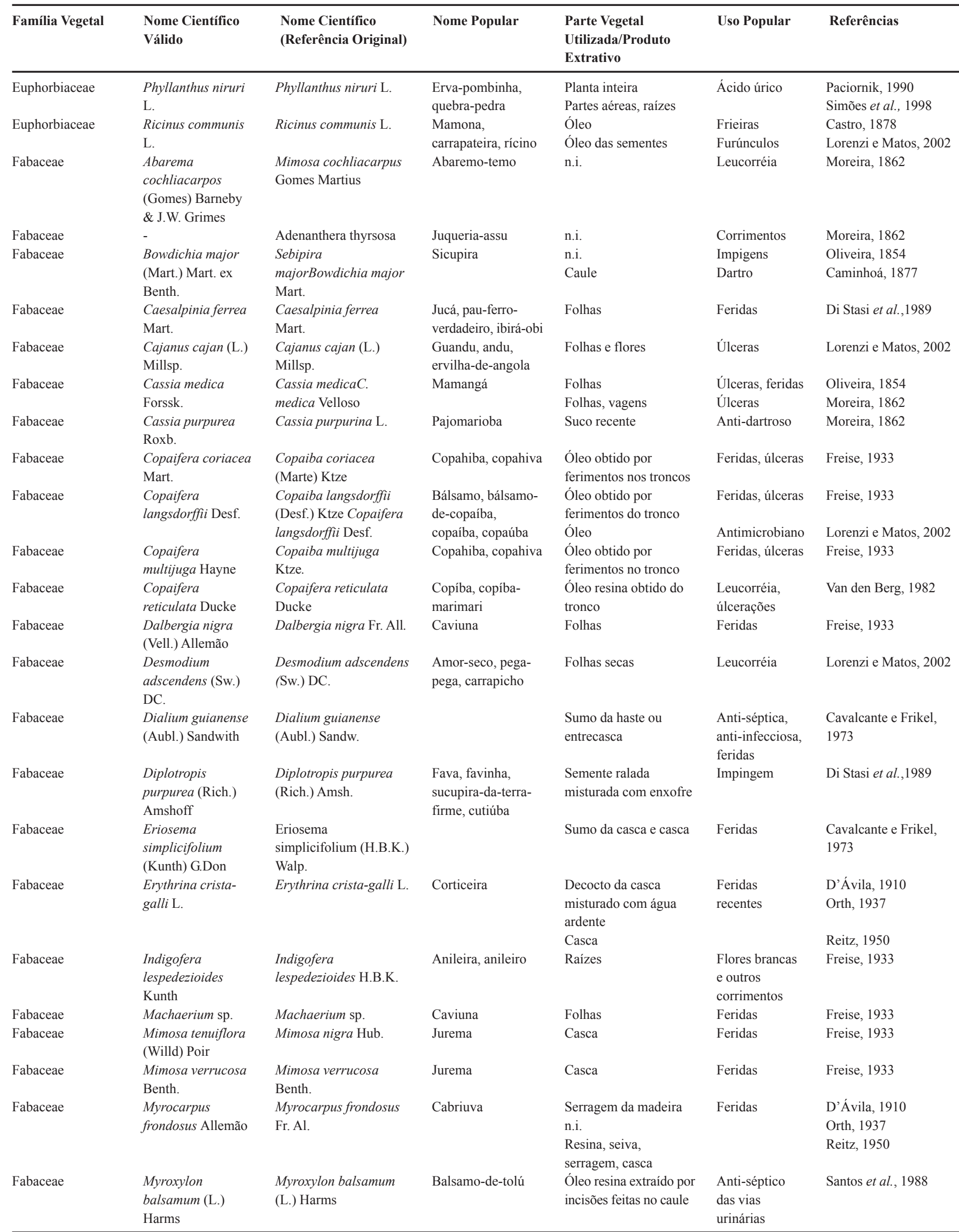


TABELA I - cont.

\begin{tabular}{|c|c|c|c|c|c|c|}
\hline Família Vegetal & $\begin{array}{l}\text { Nome Científico } \\
\text { Válido }\end{array}$ & $\begin{array}{l}\text { Nome Científico } \\
\text { (Referência Original) }\end{array}$ & Nome Popular & $\begin{array}{l}\text { Parte Vegetal } \\
\text { Utilizada/Produto } \\
\text { Extrativo }\end{array}$ & Uso Popular & Referências \\
\hline Fabaceae & $\begin{array}{l}\text { Piptadenia rigida } \\
\text { Benth. }\end{array}$ & $\begin{array}{l}\text { Piptadenia rigida } \\
\text { Benth. }\end{array}$ & Angico & Casca, goma & Leucorréia & Reitz, 1950 \\
\hline Fabaceae & $\begin{array}{l}\text { Senna alata }(\mathrm{L} .) \\
\text { Roxb. }\end{array}$ & Cassia herpetica & - & A erva & Impigens & Oliveira, 1854 \\
\hline Fabaceae & $\begin{array}{l}\text { Senna occidentalis } \\
\text { (L.) Link }\end{array}$ & $\begin{array}{l}\text { Cassia occidentalis } \\
\text { L.Senna occidentalis } \\
\text { (L.) Link }\end{array}$ & $\begin{array}{l}\text { Café-d-gozo, café- } \\
\text { de-negro, erva- } \\
\text { fedorenta, } \\
\text { fedegoso }\end{array}$ & $\begin{array}{l}\text { Semente } \\
\text { Folhas }\end{array}$ & $\begin{array}{l}\text { Micoses } \\
\text { Feridas, } \\
\text { impingem, } \\
\text { pano-branco }\end{array}$ & $\begin{array}{l}\text { Di Stasi et al., } 1989 \\
\text { Lorenzi e Matos, } 2002\end{array}$ \\
\hline Fabaceae & $\begin{array}{l}\text { Senna uniflora } \\
\text { (Mill.) H.S. Irwin } \\
\text { \& Barneby }\end{array}$ & Cassia sericca $\mathrm{Sw}$. & Fedegoso & Folhas & Anti-dartroso & Moreira, 1862 \\
\hline Fabaceae & $\begin{array}{l}\text { Stryphnodendron } \\
\text { adstringens (Mart.) } \\
\text { Coville }\end{array}$ & $\begin{array}{l}\text { Stryphnodendron } \\
\text { barbatimão Martius, } \\
\text { Acacia adstringens } \\
\text { ReiseS. barbatimão } \\
\text { Mart.S. adstringens } \\
\text { (Mart.) Coville }\end{array}$ & $\begin{array}{l}\text { Barbatimão, } \\
\text { abaremotemo, } \\
\text { casca-da- } \\
\text { virgindade }\end{array}$ & $\begin{array}{l}\text { Casca } \\
\text { n.i. } \\
\text { Casca }\end{array}$ & $\begin{array}{l}\text { Leucorréia } \\
\text { Feridas } \\
\text { Feridas e úlceras } \\
\text { Corrimento } \\
\text { vaginal }\end{array}$ & $\begin{array}{l}\text { Moreira, } 1862 \\
\text { Lorenzi e Matos, } 2002 \\
\text { Freise, } 1933 \\
\text { Guarim Neto, } 1987 \\
\text { Lorenzi e Matos, } 2002\end{array}$ \\
\hline Flacourtiaceae & $\begin{array}{l}\text { Carpotroche } \\
\text { brasiliensis (Raddi) } \\
\text { Endl. }\end{array}$ & $\begin{array}{l}\text { Carpotroche } \\
\text { brasiliensis Endl.C. } \\
\text { brasiliensis (Raddi) A. } \\
\text { Gray }\end{array}$ & $\begin{array}{l}\text { Sapucainha, } \\
\text { canudeiro, pau-de- } \\
\text { anjo }\end{array}$ & Óleo das sementes & $\begin{array}{l}\text { Dartro } \\
\text { Impingem, } \\
\text { caspa, dartro }\end{array}$ & $\begin{array}{l}\text { Freise, } 1933 \\
\text { Lorenzi e Matos, } 2002\end{array}$ \\
\hline Flacourtiaceae & $\begin{array}{l}\text { Casearia ulmifolia } \\
\text { Vahl. ex Vent. }\end{array}$ & Casearia ulmifolia & Casearia & Folhas & Úlceras & Moreira, 1871 \\
\hline Iridaceae & $\begin{array}{l}\text { Morea aphylla } \\
\text { Manso }\end{array}$ & Morea aphylla Manso & $\begin{array}{l}\text { Batatinha-do- } \\
\text { campo }\end{array}$ & n.i. & $\begin{array}{l}\text { Moléstias } \\
\text { dartrosas }\end{array}$ & Moreira, 1871 \\
\hline Iridaceae & $\begin{array}{l}\text { Poarchon } \\
\text { fluminensis (Vell.) } \\
\text { Allemão }\end{array}$ & $\begin{array}{l}\text { Sisyrinchium } \\
\text { fluminensis (Vell.), } \\
\text { Poarchon fluminensis } \\
\text { (Freire Alemão) }\end{array}$ & Maririçó & Fécula & $\begin{array}{l}\text { Moléstias } \\
\text { dartrosas }\end{array}$ & Castro, 1878 \\
\hline Iridaceae & $\begin{array}{l}\text { Sisyrinchium } \\
\text { bermudiana } \mathrm{L}\end{array}$ & $\begin{array}{l}\text { Sisyrinchium } \\
\text { bermudiana (Riedel) }\end{array}$ & Maririçó & Fecula & $\begin{array}{l}\text { Moléstias } \\
\text { dartrosas }\end{array}$ & Castro, 1878 \\
\hline Iridaceae & $\begin{array}{l}\text { Sisyrinchium } \\
\text { galaxioides Gomes }\end{array}$ & $\begin{array}{l}\text { Sisyrinchium } \\
\text { galaxioides Gomes } \\
\text { S. galaxioides } \\
\text { (B.A.Gomes) }\end{array}$ & Maririçó & Raiz doce & $\begin{array}{l}\text { Moléstias } \\
\text { dartrosas }\end{array}$ & $\begin{array}{l}\text { Moreira, } 1862 \\
\text { Castro, } 1878\end{array}$ \\
\hline Iridaceae & $\begin{array}{l}\text { Sisyrinchium } \\
\text { palmifolium } \mathrm{L} \text {. }\end{array}$ & $\begin{array}{l}\text { Sisyrinchium } \\
\text { palmaefolium } \\
\text { (V.Gomes) }\end{array}$ & Maririçó & Fécula & $\begin{array}{l}\text { Moléstias } \\
\text { dartrosas }\end{array}$ & Castro, 1878 \\
\hline Lamiaceae & $\begin{array}{l}\text { Hyptis mutabilis } \\
\text { (Rich.) Briq. }\end{array}$ & Hyptis canescens & - & n.i. & Feridas & Oliveira, 1854 \\
\hline Lamiaceae & Lamium album $\mathrm{L}$. & Lamium album $\mathrm{L}$. & Urtiga-branca & Flor & Leucorréia & Caminhoá, 1877 \\
\hline
\end{tabular}


TABELA I - cont.

\begin{tabular}{|c|c|c|c|c|c|c|}
\hline Família Vegetal & $\begin{array}{l}\text { Nome Científico } \\
\text { Válido }\end{array}$ & $\begin{array}{l}\text { Nome Científico } \\
\text { (Referência Original) }\end{array}$ & Nome Popular & $\begin{array}{l}\text { Parte Vegetal } \\
\text { Utilizada/Produto } \\
\text { Extrativo }\end{array}$ & Uso Popular & Referências \\
\hline Lamiaceae & $\begin{array}{l}\text { Lavandula } \\
\text { angustifolia Mill. }\end{array}$ & $\begin{array}{l}\text { Lavandula angustifolia } \\
\text { (L.) Miller, L. spica L., } \\
\text { L. vera De CandoleL. } \\
\text { angustifolia Mill. }\end{array}$ & $\begin{array}{l}\text { Alfazema, } \\
\text { lanvanda, lavanda- } \\
\text { inglesa }\end{array}$ & n.i. & $\begin{array}{l}\text { Antimicrobiana, } \\
\text { corrimento } \\
\text { vaginal }\end{array}$ & $\begin{array}{l}\text { Moreira Filho e } \\
\text { Goltcher, } 1972 \\
\text { Lorenzi e Matos, } 2002\end{array}$ \\
\hline Lamiaceae & $\begin{array}{l}\text { Lavandula } \\
\text { officinalis Chaix \& } \\
\text { Kitt. }\end{array}$ & $\begin{array}{l}\text { Lavandula officinallis } \\
\text { Chaix }\end{array}$ & Alfazema & n.i. & Anti-séptico & $\begin{array}{l}\text { Moreira Filho e } \\
\text { Goltcher, } 1972\end{array}$ \\
\hline Lamiaceae & $\begin{array}{l}\text { Leonotis nepetifolia } \\
\text { (L.) R. Br. }\end{array}$ & $\begin{array}{l}\text { Leonitis nepetaefolia } \\
\text { (L.) R. Brown } \\
\text { L. nepetaefolia Hort. } \\
\text { L. nepetaefolia (L.) R. Br. }\end{array}$ & $\begin{array}{l}\text { Cordão-de-frade, } \\
\text { catinga-de-mulata }\end{array}$ & $\begin{array}{l}\text { Planta florida } \\
\text { n.i. }\end{array}$ & $\begin{array}{l}\text { Úlceras } \\
\text { ácido úrico }\end{array}$ & $\begin{array}{l}\text { Reitz, 1950; Di Stasi et } \\
\text { al., } 1989 \\
\text { Lorenzi e Matos, } 2002\end{array}$ \\
\hline Lamiaceae & $\begin{array}{l}\text { Marrubium vulgare } \\
\text { L. }\end{array}$ & Marrubium vulgare L. & $\begin{array}{l}\text { Marroio, malvão, } \\
\text { bom-homem }\end{array}$ & Erva & Anti-séptico & Lorenzi e Matos, 2002 \\
\hline Lamiaceae & $\begin{array}{l}\text { Mentha x piperita } \\
\text { L. }\end{array}$ & Mentha piperita L. & $\begin{array}{l}\text { Hortelã-pimenta, } \\
\text { hortelã, menta }\end{array}$ & Folhas & Anti-séptica & Di Stasi et al.,1989 \\
\hline Lamiaceae & $\begin{array}{l}\text { Ocimum } \\
\text { gratissimum } \mathrm{L} .\end{array}$ & Ocimum gratissimum L. & Alfavaca-cravo & $\begin{array}{l}\text { Folhas ou toda parte } \\
\text { aérea }\end{array}$ & Fungicida & Matos, 1998 \\
\hline Lamiaceae & $\begin{array}{l}\text { Ocimum } \\
\text { micranthum Willd. }\end{array}$ & $\begin{array}{l}\text { Ocimum micranthum } \\
\text { Willd. }\end{array}$ & Alfavaca & Sumo das folhas & $\begin{array}{l}\text { Anti-séptico da } \\
\text { região ocular }\end{array}$ & Di Stasi et al.,1989 \\
\hline Lamiaceae & $\begin{array}{l}\text { Peltodon radicans } \\
\text { Pohl }\end{array}$ & Peltodon radicans Pohl & $\begin{array}{l}\text { Paracari, hortelã- } \\
\text { do-mato, rabugem- } \\
\text { de-cachorro }\end{array}$ & $\begin{array}{l}\text { Talo, folhas } \\
\text { Folhas, ramos }\end{array}$ & $\begin{array}{l}\text { Dartros } \\
\text { Dermatoses }\end{array}$ & $\begin{array}{l}\text { Freise, } 1933 \\
\text { Lorenzi e Matos, } 2002\end{array}$ \\
\hline Lamiaceae & $\begin{array}{l}\text { Plectranthus } \\
\text { amboinicus (Lour.) } \\
\text { Spreng. }\end{array}$ & $\begin{array}{l}\text { Plectranthus } \\
\text { amboinicus (Lour.) } \\
\text { Spreng. }\end{array}$ & $\begin{array}{l}\text { Malvarisco, } \\
\text { hortelã-graúda, } \\
\text { malva-de-cheiro }\end{array}$ & Folhas & Anti-séptica & Lorenzi e Matos, 2002 \\
\hline Lamiaceae & $\begin{array}{l}\text { Rosmarinus } \\
\text { officinalis L. }\end{array}$ & $\begin{array}{l}\text { Rosmarinus officinalis } \\
\text { L. }\end{array}$ & $\begin{array}{l}\text { Alecrim, alecrim- } \\
\text { de-cheiro, } \\
\text { rosmarino, alecrim- } \\
\text { de-jardim, alecrim- } \\
\text { verdadeiro, } \\
\text { alecrim-do-sul }\end{array}$ & $\begin{array}{l}\text { Partes aéreas } \\
\text { n.i. }\end{array}$ & $\begin{array}{l}\text { Feridas } \\
\text { Caspas e } \\
\text { prevenção da } \\
\text { calvíce } \\
\text { Antimicrobiana }\end{array}$ & $\begin{array}{l}\text { Guarim Neto, } 1987 \\
\text { Paciornik, } 1990 \\
\text { Matos, } 1998 \\
\text { Simões et al., } 1998 \\
\text { Lorenzi e Matos, } 2002\end{array}$ \\
\hline Lamiaceae & Thymus vulgaris L. & Thymus vulgaris L. & Tomilho & n.i. & Anti-séptico & $\begin{array}{l}\text { Moreira Filho \& } \\
\text { Goltcher, } 1972\end{array}$ \\
\hline Lauraceae & $\begin{array}{l}\text { Acrodiclidium } \\
\text { elaeophorum Barb. } \\
\text { Rodr. }\end{array}$ & $\begin{array}{l}\text { Acrodiclidium } \\
\text { elaiophorum Barb. }\end{array}$ & $\begin{array}{l}\text { Louro-inhamuí, } \\
\text { louro-mamri, pau- } \\
\text { de-gasolina, safrás }\end{array}$ & Resina do tronco & $\begin{array}{l}\text { Dartros, } \\
\text { Dermatoses ou } \\
\text { parasitoses do } \\
\text { couro cabeludo }\end{array}$ & Van den Berg, 1982 \\
\hline Lauraceae & $\begin{array}{l}\text { Aniba puchury- } \\
\text { minor (Mart.) Mez }\end{array}$ & $\begin{array}{l}\text { Nectadra puchury- } \\
\text { minorNectandria } \\
\text { pychurim minor }\end{array}$ & $\begin{array}{l}\text { Puchury-miri, } \\
\text { pichurim-bastardo }\end{array}$ & $\begin{array}{l}\text { Óleo da semente } \\
\text { n.i. }\end{array}$ & Leucorréia & $\begin{array}{l}\text { Oliveira, } 1854 \\
\text { Moreira, } 1862\end{array}$ \\
\hline Lauraceae & $\begin{array}{l}\text { Cinnamomum } \\
\text { zeylanicum Breyn. }\end{array}$ & $\begin{array}{l}\text { Cinnamomum } \\
\text { zeylanicum Breyn., } \\
\text { Laurus cinnamomum L. }\end{array}$ & $\begin{array}{l}\text { Canela, canela-da- } \\
\text { índia }\end{array}$ & Folhas, casca & Leucorréia & Van den Berg, 1982 \\
\hline \multirow[t]{2}{*}{ Lauraceae } & $\begin{array}{l}\text { Licaria puchury- } \\
\text { major (Mart.) }\end{array}$ & $\begin{array}{l}\text { Nectandria pychurim } \\
\text { major Ness Licaria }\end{array}$ & $\begin{array}{l}\text { Louro-puxuri, } \\
\text { puxuri, pichurim }\end{array}$ & n.i. & Leucorréia & Moreira, 1862 \\
\hline & Kosterm & $\begin{array}{l}\text { puchury-major }(\mathrm{Mez}) \\
\text { Kost, Acrodiclidium } \\
\text { puchuri-major } \mathrm{Mez}\end{array}$ & & Fruto, casca, folhas & & Van den Berg, 1982 \\
\hline Lauraceae & $\begin{array}{l}\text { Mespilodaphne } \\
\text { pretiosa Nees }\end{array}$ & Mespilodaphne pretiosa & $\begin{array}{l}\text { Pereiorá, pão ou } \\
\text { casca-preciosa }\end{array}$ & Casca & Flores brancas & Oliveira, 1854 \\
\hline Lauraceae & $\begin{array}{l}\text { Nectandra } \\
\text { elaiophora Barb. } \\
\text { Rodr. }\end{array}$ & $\begin{array}{l}\text { Nectandra elaiophora } \\
\text { Barb. }\end{array}$ & $\begin{array}{l}\text { Louro-inhamuí, } \\
\text { louro-mamri, pau- } \\
\text { de-gasolina, safrás }\end{array}$ & $\begin{array}{l}\text { Resina oleosa do } \\
\text { tronco }\end{array}$ & $\begin{array}{l}\text { Dartros, } \\
\text { Dermatoses ou } \\
\text { parasitoses, } \\
\text { principalmente } \\
\text { do couro } \\
\text { cabeludo }\end{array}$ & Van den Berg, 1982 \\
\hline Lauraceae & $\begin{array}{l}\text { Nectandra } \\
\text { puchury-minor } \\
\text { (Mart.) Ness. }\end{array}$ & $\begin{array}{l}\text { Nectandra puchurim- } \\
\text { minor Ness e Mart }\end{array}$ & Pichurim & n.i. & Leucorréia & Freise, 1933 \\
\hline
\end{tabular}


TABELA I - cont.

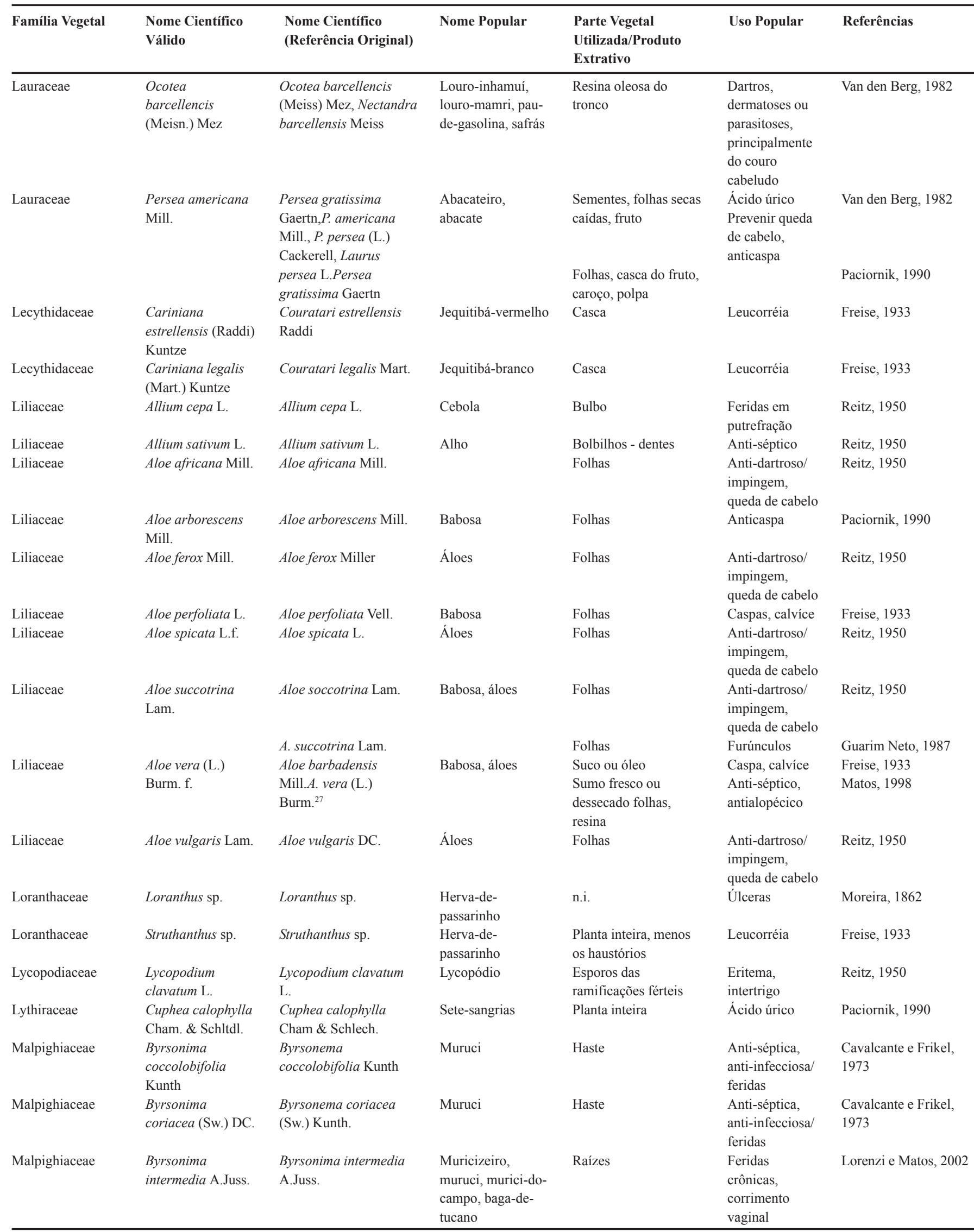


TABELA I - cont.

\begin{tabular}{|c|c|c|c|c|c|c|}
\hline Família Vegetal & $\begin{array}{l}\text { Nome Científico } \\
\text { Válido }\end{array}$ & $\begin{array}{l}\text { Nome Científico } \\
\text { (Referência Original) }\end{array}$ & Nome Popular & $\begin{array}{l}\text { Parte Vegetal } \\
\text { Utilizada/Produto } \\
\text { Extrativo }\end{array}$ & Uso Popular & Referências \\
\hline Malvaceae & $\begin{array}{l}\text { Gossypium } \\
\text { barbadense L. }\end{array}$ & Gossypium vitifolium & $\begin{array}{l}\text { Algodão- } \\
\text { americano, } \\
\text { algodoeiro, aminiiú }\end{array}$ & $\begin{array}{l}\text { Planta fresca } \\
\text { machucada } \\
\text { Folhas }\end{array}$ & $\begin{array}{l}\text { Úlceras } \\
\text { malignas } \\
\text { crônicas } \\
\text { Úlceras } \\
\text { sórdidas }\end{array}$ & Martius, 1844 \\
\hline Malvaceae & $\begin{array}{l}\text { Gossypium } \\
\text { hirsutum } \mathrm{L} .\end{array}$ & $\begin{array}{l}\text { Gossypium herbaceum } \\
\text { L. } \\
\text { Gossypium hirsutum L. }\end{array}$ & $\begin{array}{l}\text { Algodoeiro, } \\
\text { algodão, algodão- } \\
\text { herbáceo, algodão- } \\
\text { mocó }\end{array}$ & $\begin{array}{l}\text { Casca das raízes e } \\
\text { óleos das sementes } \\
\text { Flores e frutos verdes }\end{array}$ & $\begin{array}{l}\text { Úlceras } \\
\text { Micoses: } \\
\text { frieira, pano- } \\
\text { branco, } \\
\text { impingem }\end{array}$ & Lorenzi e Matos, 2002 \\
\hline Malvaceae & Malva sylvestris L. & Malva sylvestris L. & $\begin{array}{l}\text { Malva, malva-alta, } \\
\text { malva-silvestre }\end{array}$ & n.i. & Furúnculos & Lorenzi e Matos, 2002 \\
\hline Malvaceae & Sida spinosa L. & Sida spinosa L. & $\begin{array}{l}\text { Relógio, malva-de- } \\
\text { espinho }\end{array}$ & Folhas ou toda planta & Úlceras & Agra, 1996 \\
\hline Marantaceae & Thalia geniculata L. & Thalia geniculata L. & Agutiguepo-obi & Raiz & Úlceras & Moreira, 1862 \\
\hline Melastomataceae & $\begin{array}{l}\text { Comolia } \\
\text { veronicaefolia } \\
\text { Benth. }\end{array}$ & $\begin{array}{l}\text { Comolia veronicaefolia } \\
\text { Benth. }\end{array}$ & - & Folhas, hastes & $\begin{array}{l}\text { Anti-séptica e } \\
\text { cicatrizante de } \\
\text { feridas }\end{array}$ & $\begin{array}{l}\text { Cavalcante e Frikel, } \\
1973\end{array}$ \\
\hline Melastomataceae & $\begin{array}{l}\text { Lasiandra } \\
\text { mutabilis Riedel ex } \\
\text { Naudin }\end{array}$ & Lasiandra mutabilis & Cui-peuna & n.i. & Úlceras & Moreira, 1871 \\
\hline Melastomataceae & $\begin{array}{l}\text { Loreya mespiloides } \\
\text { Miq. }\end{array}$ & $\begin{array}{l}\text { Loreya mespiloides } \\
\text { Miq. }\end{array}$ & - & Sumo da entrecasca & $\begin{array}{l}\text { Anti-séptica e } \\
\text { cicatrizante de } \\
\text { feridas }\end{array}$ & $\begin{array}{l}\text { Cavalcante e Frikel, } \\
1973\end{array}$ \\
\hline Melastomataceae & $\begin{array}{l}\text { Melastoma } \\
\text { pauciflora Lam. }\end{array}$ & $\begin{array}{l}\text { Melastoma parciflora } \\
\text { Lamarck }\end{array}$ & Aninga-pari & Folhas & Úlceras & Moreira, 1862 \\
\hline Melastomataceae & $\begin{array}{l}\text { Miconia } \\
\text { aplostachya } \\
\text { (Bonpl.) DC. }\end{array}$ & $\begin{array}{l}\text { Miconia aplostachya } \\
\text { (Bonpl.) DC. }\end{array}$ & - & Folhas & $\begin{array}{l}\text { Anti-séptica e } \\
\text { cicatrizante em } \\
\text { ulcerações }\end{array}$ & $\begin{array}{l}\text { Cavalcante e Frikel, } \\
1973\end{array}$ \\
\hline Meliaceae & $\begin{array}{l}\text { Carapa guianensis } \\
\text { Aubl. }\end{array}$ & $\begin{array}{l}\text { Carapa guaianensis, } \\
\text { Xilocarpus carapaC. } \\
\text { gujanensis Aubl. } \\
\text { Martius }\end{array}$ & $\begin{array}{l}\text { Andiroba, angiroba, } \\
\text { nandiroba }\end{array}$ & $\begin{array}{l}\text { Óleo } \\
\text { Óleo } \\
\text { Fruto }\end{array}$ & $\begin{array}{l}\text { Úlceras, } \\
\text { impingem, } \\
\text { feridas } \\
\text { Feridas } \\
\text { Úlceras, } \\
\text { impingem }\end{array}$ & $\begin{array}{l}\text { Moreira,1871 } \\
\text { Moreira, } 1862\end{array}$ \\
\hline Meliaceae & $\begin{array}{l}\text { Cedrela fissilis } \\
\text { Vell. }\end{array}$ & Cedrela fissilis Vell. & Cedro & Casca, lenho & Úlceras & Reitz, 1950 \\
\hline Meliaceae & Cedrela sp. & Cedrela sp & Cedro & Cascas & Feridas & Freise, 1933 \\
\hline Menispermaceae & $\begin{array}{l}\text { Cissampelos } \\
\text { parreira Vell. }\end{array}$ & $\begin{array}{l}\text { Cissampelos parreira } \\
\text { Vell. }\end{array}$ & - & n.i. & Leucorréia & Moreira, 1862 \\
\hline Moraceae & $\begin{array}{l}\text { Brosimum } \\
\text { gaudichaudii } \\
\text { Trécul }\end{array}$ & $\begin{array}{l}\text { Brosimum gaudichaudii } \\
\text { Trécul }\end{array}$ & $\begin{array}{l}\text { Mamica-de-porco, } \\
\text { algodão-do-campo }\end{array}$ & Raízes, folhas & Dermatoses & Lorenzi e Matos, 2002 \\
\hline Moraceae & $\begin{array}{l}\text { Dorstenia arifolia } \\
\text { Lam. }\end{array}$ & $\begin{array}{l}\text { Dorstenia arilifolia } \\
\text { Lam. }\end{array}$ & Carapia & Raiz & Leucorréia & Moreira, 1862 \\
\hline Moraceae & $\begin{array}{l}\text { Dorstenia } \\
\text { brasiliensis Lam. }\end{array}$ & $\begin{array}{l}\text { Dorstenia brasiliensis } \\
\text { Lam. }\end{array}$ & Caá-piá, carapia & $\begin{array}{l}\text { Raiz } \\
\text { n.i. }\end{array}$ & Leucorréia & $\begin{array}{l}\text { Moreira, } 1862 \\
\text { Castro, } 1878\end{array}$ \\
\hline Moraceae & $\begin{array}{l}\text { Dorstenia } \\
\text { cordifolia Lam. }\end{array}$ & $\begin{array}{l}\text { Dorstenia cordifolia } \\
\text { Swartz }\end{array}$ & Contraierva & Raiz & Leucorréia & Moreira, 1862 \\
\hline Moraceae & Morus nigra $\mathrm{L}$. & Morus nigra L. & Amora & $\begin{array}{l}\text { Suco de amora, fruto, } \\
\text { casca da raiz }\end{array}$ & Aftas & Reitz, 1950 \\
\hline Moringaceae & $\begin{array}{l}\text { Moringa oleifera } \\
\text { Lam. }\end{array}$ & Moringa oleifera Lam. & $\begin{array}{l}\text { Moringa, cedro, } \\
\text { quiabo-de-quina }\end{array}$ & Sementes & Antimicrobiana & Lorenzi e Matos, 2002 \\
\hline Musaceae & $\begin{array}{l}\text { Musa paradisiaca } \\
\text { L. }\end{array}$ & Musa paradisiaca $\mathrm{L}$. & $\begin{array}{l}\text { Bananeira-de-são- } \\
\text { thomé }\end{array}$ & $\begin{array}{l}\text { Folhas } \\
\text { Suco da raiz e tronco, } \\
\text { folhas, frutos e flores }\end{array}$ & $\begin{array}{l}\text { Aftas, } \\
\text { leucorréia } \\
\text { Flores brancas }\end{array}$ & $\begin{array}{l}\text { Moreira, } 1862 \\
\text { Reitz, } 1954\end{array}$ \\
\hline Musaceae & Musa sapientum L. & Musa sapientum L. & Bananeira & Folhas, tronco & $\begin{array}{l}\text { Úlceras, } \\
\text { feridas, } \\
\text { sapinhos das } \\
\text { crianças }\end{array}$ & Reitz, 1954 \\
\hline
\end{tabular}


TABELA I - cont.

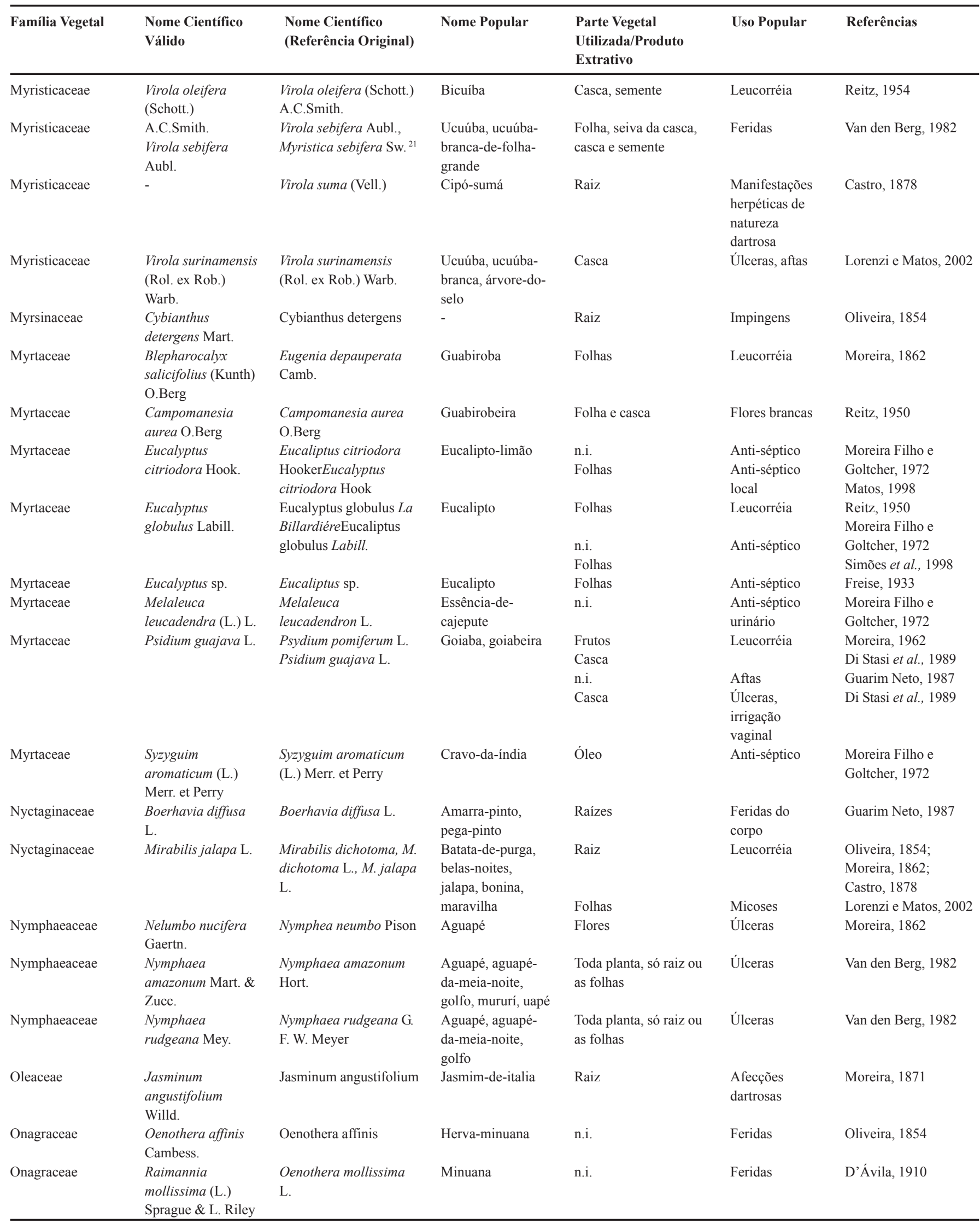


TABELA I - cont.

\begin{tabular}{|c|c|c|c|c|c|c|}
\hline Família Vegetal & $\begin{array}{l}\text { Nome Científico } \\
\text { Válido }\end{array}$ & $\begin{array}{l}\text { Nome Científico } \\
\text { (Referência Original) }\end{array}$ & Nome Popular & $\begin{array}{l}\text { Parte Vegetal } \\
\text { Utilizada/Produto } \\
\text { Extrativo }\end{array}$ & Uso Popular & Referências \\
\hline Phytolaccaceae & $\begin{array}{l}\text { Petiveria alliacea } \\
\text { L. }\end{array}$ & Petivera alliacea $\mathrm{L}$. & $\begin{array}{l}\text { Mocura-caá, tipi, } \\
\text { amansa-senhor }\end{array}$ & Folhas & Anti-séptica & Di Stasi et al.,1989 \\
\hline Piperaceae & $\begin{array}{l}\text { Peperomia } \\
\text { elongata Kunth }\end{array}$ & $\begin{array}{l}\text { Peperomia elongata } \\
\text { H.B.K., P. myriocarpa } \\
\text { C. DC., P. controversa } \\
\text { C. DC., Piper extensum } \\
\text { Roem }\end{array}$ & Erva-de-soldado & $\begin{array}{l}\text { Folhas, } \\
\text { inflorescências }\end{array}$ & Leucorréia & Van den Berg, 1982 \\
\hline Piperaceae & Piper umbellatum $\mathrm{L}$. & Piper umbellatum Vell. & Periparoba & Raiz & Leucorréia & Moreira, 1871 \\
\hline Piperaceae & $\begin{array}{l}\text { Pothomorphe } \\
\text { peltata (L.) Miq. }\end{array}$ & Piper peltatum & - & Raiz & Úlceras & Oliveira, 1854 \\
\hline Piperaceae & $\begin{array}{l}\text { Pothomorphe } \\
\text { umbellata (L.) Miq. }\end{array}$ & $\begin{array}{l}\text { Pothomorphe umbellata } \\
\text { (L.) Miq. }\end{array}$ & $\begin{array}{l}\text { Pariparoba, } \\
\text { aguaxima, caapeba }\end{array}$ & Folhas & Furúnculos & Lorenzi e Matos, 2002 \\
\hline Plantaginaceae & $\begin{array}{l}\text { Plantago australis } \\
\text { Lam. }\end{array}$ & Plantago australis Lam. & $\begin{array}{l}\text { Tanchagem, } \\
\text { tanchás }\end{array}$ & Folhas & Feridas & Freise, 1933 \\
\hline Plantaginaceae & Plantago major $\mathrm{L}$. & Plantago major $\mathrm{L}$. & $\begin{array}{l}\text { Tanchagem, } \\
\text { tanchás }\end{array}$ & Folhas & Feridas & Paciornik, 1990 \\
\hline Plumbaginaceae & $\begin{array}{l}\text { Limonium } \\
\text { brasiliense (Boiss.) } \\
\text { Kuntze }\end{array}$ & $\begin{array}{l}\text { Statice braziliensis } \\
\text { Boiss Limonium } \\
\text { brasiliense (Boiss.) } \\
\text { Kuntze }\end{array}$ & Baicuru, guaicuru & Raiz & $\begin{array}{l}\text { Úlceras } \\
\text { rebeldes } \\
\text { Leucorréia }\end{array}$ & $\begin{array}{l}\text { Freise, } 1933 \\
\text { Simões } \text { et al., } 1998\end{array}$ \\
\hline Poaceae & $\begin{array}{l}\text { Gynerium } \\
\text { sagittatum (Aubl.) } \\
\text { P.Beauv. }\end{array}$ & $\begin{array}{l}\text { Gynerium parviflorum } \\
\text { G. saccharoides Bompl. }\end{array}$ & Vuba & Raiz & $\begin{array}{l}\text { Queda de } \\
\text { cabelos }\end{array}$ & $\begin{array}{l}\text { Oliveira, } 1854 \\
\text { Moreira, } 1862\end{array}$ \\
\hline Poaceae & $\begin{array}{l}\text { Saccharum } \\
\text { officinarum } \mathrm{L} \text {. }\end{array}$ & $\begin{array}{l}\text { Saccharum officinarum } \\
\text { L. }\end{array}$ & $\begin{array}{l}\text { Cana-de-açúcar, } \\
\text { cana }\end{array}$ & $\begin{array}{l}\text { Suco do colmo da } \\
\text { planta }\end{array}$ & Aftas & Di Stasi et al.,1989 \\
\hline Poligonaceae & $\begin{array}{l}\text { Coccoloba } \\
\text { crescentiaefolia } \\
\text { Cham. }\end{array}$ & $\begin{array}{l}\text { Coccoloba } \\
\text { crescentiaefoliaC. } \\
\text { crescentiaefolia } \text { Cham }\end{array}$ & $\begin{array}{l}\text { Tangaraca-guaçú, } \\
\text { tangaraca-assú, } \\
\text { tangara-guaçu-caa }\end{array}$ & Fruto & Leucorréia & $\begin{array}{l}\text { Oliveira, } 1854 \\
\text { Caminhoá, } 1877\end{array}$ \\
\hline Poligonaceae & $\begin{array}{l}\text { Coccoloba uvifera } \\
\text { (L.) L. }\end{array}$ & Coccoloba uvifera $\mathrm{L}$. & Baga-da-praia & Fruto & Leucorréia & Caminhoá, 1877 \\
\hline Polygonaceae & $\begin{array}{l}\text { Polygonum acre } \\
\text { Lam. }\end{array}$ & Polygonum acre HBK & Erva-de-bicho & Planta inteira & $\begin{array}{l}\text { Aliviar } \\
\text { corrimentos nas } \\
\text { mulheres }\end{array}$ & Paciornik, 1990 \\
\hline Polygonaceae & Rumex crispus $\mathrm{L}$. & Rumex crispus $\mathrm{L}$. & Labaça & Folhas, raízes & Dartros & Freise, 1933 \\
\hline Polygonaceae & $\begin{array}{l}\text { Rumex obtusifolius } \\
\text { L. }\end{array}$ & Rumex obtusifolius L. & Labaça & Folhas, raízes & Dartros & Freise, 1933 \\
\hline Portulacaceae & $\begin{array}{l}\text { Portulaca oleracea } \\
\text { L. }\end{array}$ & Portulaca oleracea $\mathrm{L}$. & Beldroega & Folhas,caule, sementes & Úlceras & Reitz, 1950 \\
\hline Portulacaceae & Portulaca pilosa $\mathrm{L}$. & Portulaca pilosa $\mathrm{L}$. & Amor-crescido & $\begin{array}{l}\text { Folhas } \\
\text { Folhas, hastes e raiz }\end{array}$ & $\begin{array}{l}\text { Feridas } \\
\text { Úlceras }\end{array}$ & Freise, 1933 \\
\hline Portulacaceae & $\begin{array}{l}\text { Talinum } \\
\text { paniculatum (Jacq.) } \\
\text { Gaern. }\end{array}$ & $\begin{array}{l}\text { Talinum paniculatum } \\
\text { (Jacq.) Gaern. }\end{array}$ & $\begin{array}{l}\text { Língua-de-vaca, } \\
\text { caruru, maria-gorda }\end{array}$ & Folhas & Feridas & $\begin{array}{l}\text { Van den Berg, } 1982 \\
\text { Lorenzi e Matos, } 2002\end{array}$ \\
\hline
\end{tabular}


TABELA I - cont.

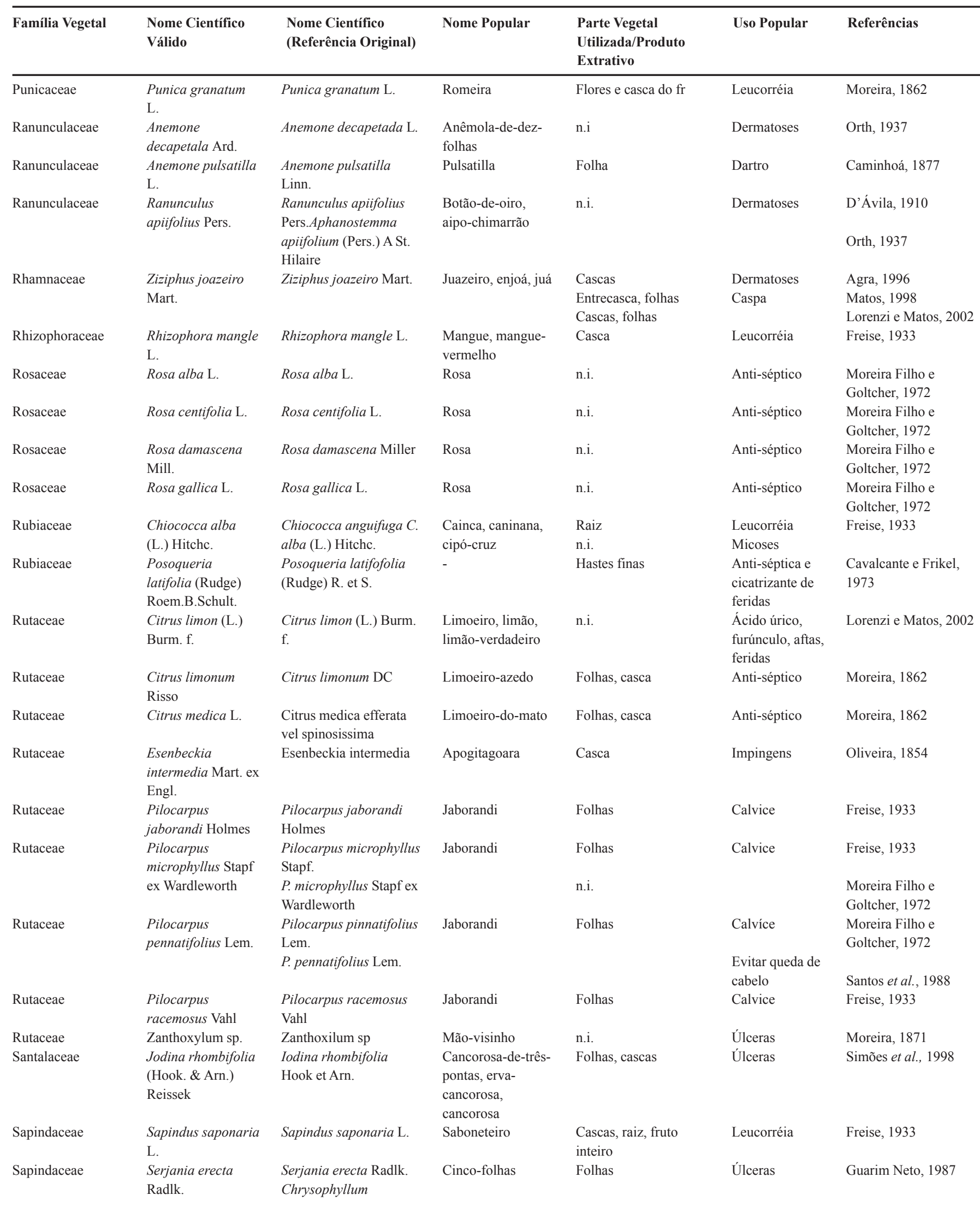


TABELA I - cont.

\begin{tabular}{|c|c|c|c|c|c|c|}
\hline Família Vegetal & $\begin{array}{l}\text { Nome Científico } \\
\text { Válido }\end{array}$ & $\begin{array}{l}\text { Nome Científico } \\
\text { (Referência Original) }\end{array}$ & Nome Popular & $\begin{array}{l}\text { Parte Vegetal } \\
\text { Utilizada/Produto } \\
\text { Extrativo }\end{array}$ & Uso Popular & Referências \\
\hline Sapotaceae & $\begin{array}{l}\text { Pradosia } \\
\text { lactescens (Vell.) } \\
\text { Radlk. }\end{array}$ & $\begin{array}{l}\text { buranhemC. buranhem } \\
\text { RiedelLucuma } \\
\text { glycyphlola Mart e } \\
\text { Eiche }\end{array}$ & $\begin{array}{l}\text { Buranhem, } \\
\text { monesia, } \\
\text { guaranhem }\end{array}$ & $\begin{array}{l}\text { n.i. } \\
\text { Casca } \\
\text { Casca }\end{array}$ & $\begin{array}{l}\text { Leucorréia } \\
\text { Úlceras } \\
\text { cutâneas }\end{array}$ & $\begin{array}{l}\text { Oliveira, } 1854 \\
\text { Moreira, } 1862 \\
\text { Freise, } 1933\end{array}$ \\
\hline Scrophulariaceae & Scoparia dulcis L. & Scoparia dulcis L. & $\begin{array}{l}\text { Tapixaba, fel-da- } \\
\text { terra, vassourinha }\end{array}$ & Toda planta & $\begin{array}{l}\text { Corrimento } \\
\text { vaginal }\end{array}$ & Di Stasi et al.,1989 \\
\hline Selaginellaceae & $\begin{array}{l}\text { Selaginella pedata } \\
\text { Klotzsch }\end{array}$ & $\begin{array}{l}\text { Selaginella pedata } \\
\text { Klotz. }\end{array}$ & - & Folhas & $\begin{array}{l}\text { Feridas, anti- } \\
\text { séptica }\end{array}$ & $\begin{array}{l}\text { Cavalcante e Frikel, } \\
1973\end{array}$ \\
\hline Simaroubaceae & - & Simarouba officinalis & Marubá & n.i. & Leucorréia & Moreira, 1862 \\
\hline Smilacaceae & $\begin{array}{l}\text { Smilax papyracea } \\
\text { Duhamel }\end{array}$ & Smilax papyracea & Sipó-em & Fécula & $\begin{array}{l}\text { Moléstias } \\
\text { dartrosas }\end{array}$ & $\begin{array}{l}\text { Castro, } 1878 \text { ou } \\
\text { Oliveira, } 1854\end{array}$ \\
\hline Smilacaceae & $\begin{array}{l}\text { Smilax siphilitica } \\
\text { Humb. et Bonpl. ex } \\
\text { Willd. }\end{array}$ & Smilax siphilitica & Sipó-em & Fécula & $\begin{array}{l}\text { Moléstias } \\
\text { dartrosas }\end{array}$ & $\begin{array}{l}\text { Castro, } 1878 \mathrm{Ou} \\
\text { Oliveira, } 1854\end{array}$ \\
\hline Solanaceae & $\begin{array}{l}\text { Cestrum } \\
\text { laevigatum Schltdl. }\end{array}$ & $\begin{array}{l}\text { Cestrum laevigatum } \\
\text { Schltdl. }\end{array}$ & Coearana & Folhas, talos & Anti-séptico & Freise, 1933 \\
\hline Solanaceae & $\begin{array}{l}\text { Cestrum } \\
\text { salicifolium Jacq. }\end{array}$ & $\begin{array}{l}\text { Cestrum salicifolium } \\
\text { Jacq. }\end{array}$ & Coearana & Folhas, talos & Anti-séptico & Freise, 1933 \\
\hline Solanaceae & $\begin{array}{l}\text { Cestrum stipulatum } \\
\text { Vell. }\end{array}$ & $\begin{array}{l}\text { Cestrum bracteatum, } C \text {. } \\
\text { stipulatum } C \text {. } \\
\text { bracteatum Link }\end{array}$ & Piranga, coearana & $\begin{array}{l}\text { n.i. } \\
\text { Folhas, talos }\end{array}$ & $\begin{array}{l}\text { Úlceras e } \\
\text { feridas } \\
\text { Anti-séptico }\end{array}$ & $\begin{array}{l}\text { Oliveira, } 1854 \\
\text { Freise, } 1933\end{array}$ \\
\hline Solanaceae & $\begin{array}{l}\text { Lycopersicum } \\
\text { esculentum Mill. }\end{array}$ & $\begin{array}{l}\text { Lycopersicum } \\
\text { esculentum Mill. }\end{array}$ & Tomate & Fruto & $\begin{array}{l}\text { Antifúngico } \\
\text { local }\end{array}$ & Matos, 1998 \\
\hline Solanaceae & $\begin{array}{l}\text { Solanum } \\
\text { americanum Mill. }\end{array}$ & $\begin{array}{l}\text { Solanum americanum } \\
\text { Mill. }\end{array}$ & $\begin{array}{l}\text { Maria-preta, erva- } \\
\text { de-bicho, erva- } \\
\text { mocó }\end{array}$ & Folhas & $\begin{array}{l}\text { Úlceras, } \\
\text { feridas, } \\
\text { furúnculos }\end{array}$ & Lorenzi e Matos, 2002 \\
\hline Solanaceae & $\begin{array}{l}\text { Solanum cernuum } \\
\text { Vell. }\end{array}$ & Solanum cernuum Vell. & $\begin{array}{l}\text { Panacéia, braço-de- } \\
\text { preguiça, erva- } \\
\text { carneira }\end{array}$ & $\begin{array}{l}\text { Folhas, flores } \\
\text { Raiz, folhas } \\
\text { Folhas }\end{array}$ & $\begin{array}{l}\text { Úlceras } \\
\text { Dartros } \\
\text { Furúnculo }\end{array}$ & $\begin{array}{l}\text { Moreira, } 1862 \\
\text { Freise, } 1933 \\
\text { Lorenzi e Matos, } 2002\end{array}$ \\
\hline Solanaceae & $\begin{array}{l}\text { Solanum } \\
\text { dulcamara } \mathrm{L} .\end{array}$ & $\begin{array}{l}\text { Solanum dulcamarca } \\
\text { Linn. }\end{array}$ & $\begin{array}{l}\text { Dulcamarca, doce- } \\
\text { amarga }\end{array}$ & Caule & Dartro & Caminhoá, 1877 \\
\hline Solanaceae & $\begin{array}{l}\text { Solanum jubeba } \\
\text { Vell. }\end{array}$ & Solanum jubeba & Juripeba, jurepeba & Folhas, frutos & $\begin{array}{l}\text { Feridas e } \\
\text { úlceras }\end{array}$ & Oliveira, 1854 \\
\hline Solanaceae & Solanum nigrum L. & Solanum nigrum L. & $\begin{array}{l}\text { Herva-moura, } \\
\text { herva-de-bicho }\end{array}$ & Planta inteira & Leucorréia & Freise, 1933 \\
\hline Solanaceae & $\begin{array}{l}\text { Solanum } \\
\text { paniculatum } \mathrm{L} .\end{array}$ & $\begin{array}{l}\text { Solanum paniculatum S. } \\
\text { paniculatum }\end{array}$ & Juripeba, jurubeba & $\begin{array}{l}\text { Folhas, frutos } \\
\text { Frutos }\end{array}$ & $\begin{array}{l}\text { Úlceras } \\
\text { Feridas }\end{array}$ & $\begin{array}{l}\text { Oliveira, } 1854 \\
\text { Moreira, } 1862\end{array}$ \\
\hline Solanaceae & $\begin{array}{l}\text { Solanum tuberosum } \\
\text { L. }\end{array}$ & Solanum tuberosum L. & Batata-inglesa & $\begin{array}{l}\text { Tubérculo, folhas } \\
\text { frescas, flores }\end{array}$ & Úlceras, feridas & Reitz, 1954 \\
\hline Sterculiaceae & $\begin{array}{l}\text { Guazuma ulmifolia } \\
\text { Lam. }\end{array}$ & $\begin{array}{l}\text { Guazuma ulmifolia } \\
\text { Lam. }\end{array}$ & Embirú & $\begin{array}{l}\text { Cascas } \\
\text { Entrecasca }\end{array}$ & $\begin{array}{l}\text { Úlceras da pele } \\
\text { Queda de } \\
\text { cabelos ou } \\
\text { moléstias } \\
\text { parasitárias do } \\
\text { couro cabeludo }\end{array}$ & $\begin{array}{l}\text { D’Ávila, } 1910 \\
\text { Orth, } 1937 \\
\text { Freise, } 1933\end{array}$ \\
\hline Sterculiaceae & Helicteres sp. & Helicteres sp. & Sacarolha & Raiz & Flores brancas & Freise, 1933 \\
\hline Sterculiaceae & $\begin{array}{l}\text { Waltheria } \\
\text { douradinha A.St.- } \\
\text { Hil. }\end{array}$ & $\begin{array}{l}\text { Waltheria douradinha } \\
\text { St. Hil. }\end{array}$ & $\begin{array}{l}\text { Douradinha, } \\
\text { douradinha-do- } \\
\text { campo }\end{array}$ & $\begin{array}{l}\text { Folhas, flores ou toda } \\
\text { planta } \\
\text { Folhas } \\
\text { Planta inteira florida }\end{array}$ & Úlceras & $\begin{array}{l}\text { D’Ávila, } 1910 \\
\text { Orth, } 1937 \\
\text { Simões et al., } 1998 \\
\text { Simões et al., } 1998\end{array}$ \\
\hline Styracaceae & - & Styrax ariculatum & Estoraque & Bálsamo & $\begin{array}{l}\text { Úlceras, } \\
\text { leucorréia }\end{array}$ & Moreira, 1862 \\
\hline Styracaceae & $\begin{array}{l}\text { Styrax benjoin } \\
\text { Dryand. }\end{array}$ & $\begin{array}{l}\text { Styrax benjoin } \\
\text { Dryander }\end{array}$ & $\begin{array}{l}\text { Benjoim-de- } \\
\text { sumatra }\end{array}$ & Resina & Anti-séptico & $\begin{array}{l}\text { Moreira Filho e } \\
\text { Goltcher, } 1972\end{array}$ \\
\hline Styracaceae & $\begin{array}{l}\text { Styrax ferrugineus } \\
\text { Nees \& Mart. }\end{array}$ & $\begin{array}{l}\text { Styrax ferrugineum } \\
\text { Martius }\end{array}$ & Estoraque & Bálsamo & $\begin{array}{l}\text { Úlceras, } \\
\text { leucorréia }\end{array}$ & Moreira, 1862 \\
\hline Styracaceae & $\begin{array}{l}\text { Styrax } \\
\text { paralleloneurus } \\
\text { Perkins }\end{array}$ & $\begin{array}{l}\text { Styrax paralleloneurus } \\
\text { Perkins }\end{array}$ & $\begin{array}{l}\text { Benjoim-de- } \\
\text { sumatra }\end{array}$ & Resina & Anti-séptico & $\begin{array}{l}\text { Moreira Filho e } \\
\text { Goltcher, } 1972\end{array}$ \\
\hline
\end{tabular}


TABELA I - cont.

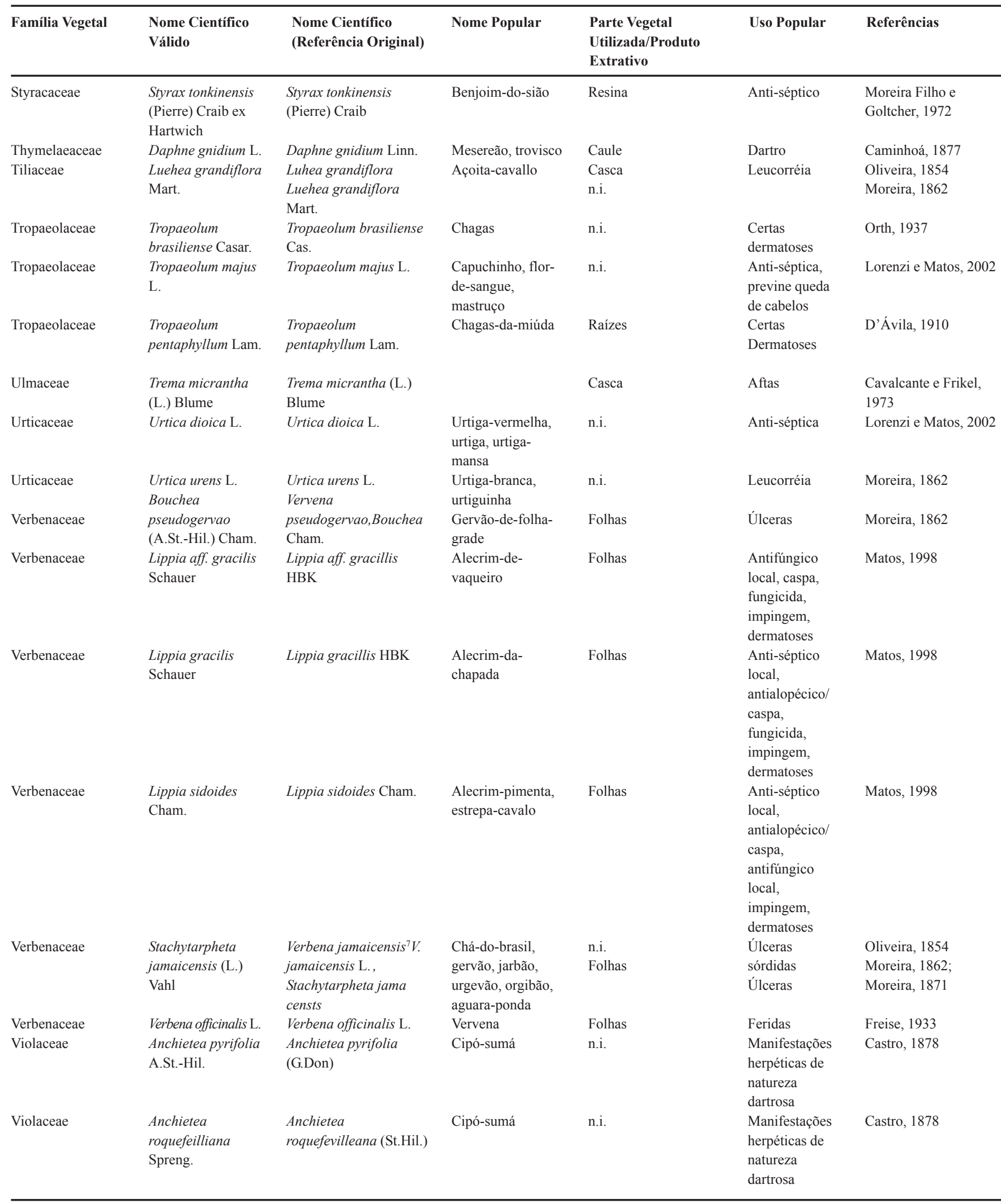


TABELA I - cont.

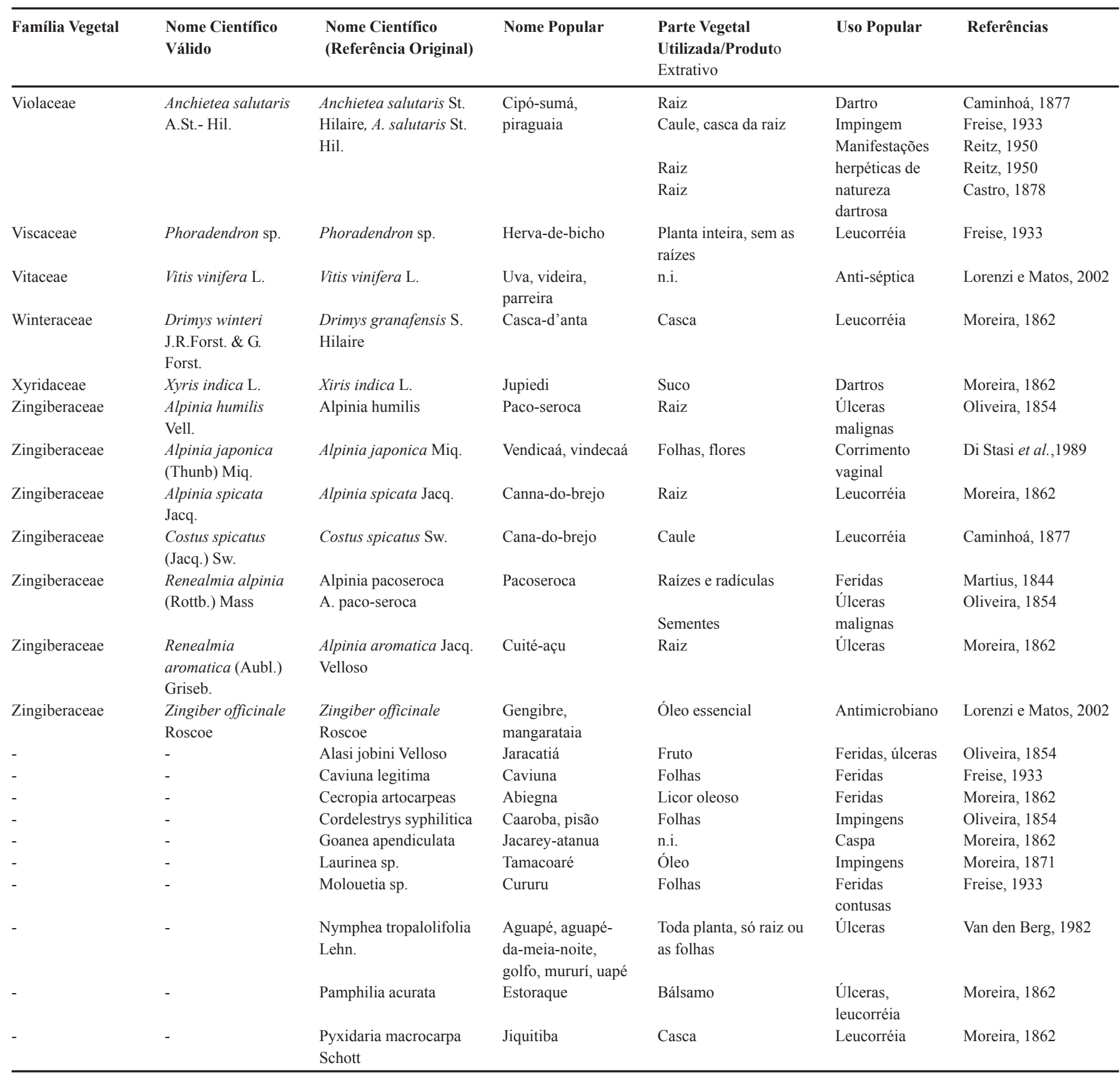

(n.i.): não informado(a); (-): não consta na bibliografia consultada

Com relação aos dados publicados, destaca-se a atividade antifúngica dos óleos voláteis, presentes em Rosmarinus officialis e Schinus molle e a atividade de defesa contra fitopatógenos encontrada para proteínas de Phytolacca americana e Mirabilis jalapa. Os óleos voláteis têm sua atividade anti-séptica reconhecida e normalmente atribuída à presença de compostos fenólicos, aldeídos e álcoois: citral, geraniol, linalol e timol têm alto poder anti-séptico, superior ao do próprio fenol (Simões e Spitzer, 2003). Os óleos voláteis da família Lamiaceae, a qual pertence $R$. officinalis, apresentam grande importância econômica e várias espécies são cultivadas para utilização na indústria de alimentos, cosméticos e, também, para fins medicinais (Simões et al., 2003). O fato de as proteínas de Phytolacca americana e Mirabilis jalapa apresentarem sequências homólogas 
TABELA II - Espécies mais citadas como úteis em sinais e sintomas indicativos de infecções fúngicas.

\begin{tabular}{llll}
\hline Espécie & Família & $\mathrm{N}^{0}$ citações & Publicações sobre a comprovação da atividade antifúngica \\
& Botânica & referentes ao & \\
& uso medicinal \\
& como antifúngico
\end{tabular}

\begin{tabular}{|c|c|}
\hline $\begin{array}{l}\text { Anacardium } \\
\text { occidentale L. }\end{array}$ & Anacardiaceae \\
\hline Cecropia peltata $\mathrm{L}$. & Cecropiaceae \\
\hline $\begin{array}{l}\text { Phytolacca } \\
\text { americana } \mathrm{L} .\end{array}$ & Phytolaccaceae \\
\hline
\end{tabular}

americana $\mathrm{L}$.

Rosmarinus Lamiaceae

officinalis L.

Anchietea salutaris

A.St.-Hil.

Mirabilis jalapa L. Nyctaginaceae

Schinus molle L.

Anacardiaceae

Anacardiaceae

Schinus

terebinthifolius

Raddi

Stryphnodendron

adstringens (Mart.)

Coville

Tabebuia

heptaphylla (Vell.)

Toledo

Fabaceae

Bignonaceae
5

5 Lectinas no diagnóstico de fungos (in vitro);

Fitolacosídeo B ativo contra Cladosporium herbarum;

Proteína antiviral isolada (PAP) em espécies mutantes ativa contra

fungos fitopatogênicos;

Peptídeo de P. americana (PAP-s) exibiu amplo espectro de atividade antifúngica;

Proteína rica em cisteína (Pa-AMP) inibiu o crescimento de alguns

fungos fitopatogênicos; proteína possui seqüência de aminoácidos

homóloga a uma proteína de Mirabilis jalapa;

As raízes secretam um exudato que contém uma proteína inativadora

de ribossomos, e esse tem atividade (in vitro) contra fungos

fitopatogênicos.

$5 \quad$ Óleo volátil ativo contra Saccharomyces cerevisiae e Candida

albicans (in vitro);

Atividade contra fungos filamentosos e leveduras;

Efeito (in vitro) contra fungos que infectam alimentos e cosméticos;

Atividade contra Penicillium digitatum, um fungo patógeno de

espécies de Citrus (in vitro);

Inibição do crescimento de Aspergillus niger e A. flavus (in vitro).

n.c

Dois peptídeos isolados (Mj-AMP1 e Mj-AMP2) de $M$. jalapa

exibiram atividade contra 13 fungos patógenos de plantas (in vitro).

Esses peptídeos têm semelhança na seqüência de aminoácidos e o

mesmo resíduo de cisteína de um peptídeo de Phytolacca americana

(PAFP-s), que exibiu largo espectro de atividade antifúngica;

Uma isoflavona e um diidrorotenóide isolados de uma cultura de

células de $M$. jalapa foram identificados como substâncias

antifúngicas principais, em ensaios in vitro contra Candida albicans.

Óleo volátil apresentou atividade fungitóxica máxima contra fungos

patógenos de animais (Microsporum gypseum, Trichophyton

mentagrophytes, T. rubrum) e atividade moderada contra fungos

oportunistas (Alternaria alternata, Aspergillus flavus, Penicillium

italicum);

Espécies de Aspergillus ochraceus, A. parasiticus, Fusarium

culmorum e Alternaria alternata mostraram-se sensíveis ao óleo

volátil de $S$. molle.

4

4

n.c.

4
Karayannopoulou et al., 1988

Kobayashi et al., 1995.

Zoubenko et al., 1997;

Zoubenko et al., 2000

Sha et al., 1999

Liu et al., 2000

Park et al., 2002

Panizzi et al., 1993

Larrondo et al., 1995

Mangena e Muyima, 1999

Daferrera et al., 2000

Shin, 2003

Cammue et al., 1992; Sha et al., 1999

Yang et al. ,2001

Dikshit et al., 1986

Gunzidza, 1993

(n.c.) $=$ não consta na literatura consultada

e atividades biológicas semelhantes é muito interessante, visto que as famílias Phytolaccaceae e Nyctaginaceae são filogeneticamente relacionadas e ambas pertencem à ordem Caryophyllales (Judd et al., 1999). No entanto, não foi possível estabelecer a partir deste trabalho, uma relação entre a constituição química das plantas e os usos populares indicativos de atividade antifúngica. Isto não é surpreendente, visto que a atividade antifúngica tem 
sido documentada para várias classes de metabólitos secundários vegetais, na maioria das vezes sem um alvo específico (Zacchino, 2001).

Entre as dez espécies avaliadas, seis correspondem a espécies nativas: Anacardium occidentale L., Cecropia peltata L., Anchietea salutaris A.St.-Hil., Schinus molle L., Schinus terebinthifolius Raddi, Stryphnodendron adstringens (Mart.) Coville e Tabebuia heptaphylla (Vell.) Toledo. A. occidentale ocorre em campos e dunas da costa norte do Brasil, especialmente nos estados do Maranhão e Piauí (Lorenzi, Matos, 2002; W³ TROPICOS, 2006); Cecropia peltata, na Amazônia e mata atlântica (Di Stasi, 2002); Schinus molle, no sul do Brasil (Lorenzi e Matos, 2002; W TROPICOS, 2006). Schinus terebinthifolius, ao longo da mata atlântica, desde o Rio Grande do Norte até o Rio Grande do Sul (Lorenzi, Matos, 2002; W3 TROPICOS). Stryphnodendron adstringens, nos cerrados do Sudeste e Centro-Oeste (Lorenzi, Matos, 2002; $\mathrm{W}^{3}$ TROPICOS, 2006) e Tabebuia heptaphylla, em Santa Catarina, São Paulo e Bahia (W³ TROPICOS, 2006). Essas espécies são ainda preservadas, não sendo vulneráveis ou ameaçadas de extinção (BIODIVERSITAS, 2006). Apenas para Schinus molle foram encontrados dados de atividade antifúngica, indicando que, apesar da diversidade de espécies do nosso país, a grande maioria ainda não foi objeto de avaliação de um potencial efeito antifúngico.

\section{CONCLUSÕES}

Neste trabalho foi encontrado um número significativo (409) de espécies mencionadas na literatura etnobotânica brasileira como úteis para o tratamento de sinais e sintomas indicativos de ação antifúngica, distribuídas principalmente em duas famílias: Fabaceae e Asteraceae. Porém, entre as 10 espécies com maior número de citações, a maioria não pertence a estas famílias. Considerando a necessidade premente de novos antifúngicos eficazes e que, reconhecidamente, o estudo da utilização popular de plantas medicinais é uma ferramenta importante no descobrimento de novos fármacos, estes resultados apontam para a flora brasileira como alvo para pesquisa e desenvolvimento de novas substâncias com atividade antifúngica. No entanto, os dados publicados sobre avaliação da potencial atividade antifúngica destas espécies é ainda escarço, sendo que entre as espécies nativas mais citadas, apenas uma foi investigada.

\section{AGRADECIMENTOS}

Este trabalho foi realizado com apoio do Projeto X.7 do CYTED e AUGM ( Associação das Universidades do Grupo Montevidéu).

\section{ABSTRACT}

\section{Plants with potencial antifungal activity employed in brazilian folk medicine}

The aim of this work was to draw up a list of plants used by Brazilian population for the treatment of signs and symptoms related to fungal infections and to verify the existence of scientific data related to the antifungal activity in the databasis MEDLINE-PubMed. Four hundread and nine species were listed, which are distributed in ninety eight families, mainly Fabaceae and Asteraceae. Among the more frequently mentioned species (10), only four were evaluated regarding to the antifungal activity: Phytolacca americana $L$., Rosmarinus officinalis $L$., Mirabilis jalapa $L$. and Schinus molle L. From those ten species, six are native (Anacardium occidentale $L$., Cecropia peltata $L$., Schinus molle L., Schinus terebinthifolius Raddi, Stryphnodendron adstringens (Mart.) Coville e Tabebuia heptaphylla (Vell.) Toledo.

UNITERMS: Medicinal plants. Antifungal activity. Folk medicine.

\section{REFERÊNCIAS BIBLIOGRÁFICAS}

AGRA, M. DE F. Plantas da medicina popular dos Cariris Velhos, Paraíba, Brasil. João Pessoa: Ed. União, 1996. $125 \mathrm{p}$.

BIODIVERSITASDisponivelem: < http:/wwww.biodiversitas.org.br $>$ Acesso em: 18 out. 2004

CAMINHOÁ, J.M. Elementos de botânica geral e médica. Rio de Janeiro: Typographia Nacional. 1877.

CAMMUE, B.P.; DE BOLLE, M.F.; TERRAS, F.R.; PROOOST, P.; VAN DAMME, J.; REES, S.; VANDERLEYDEN, J.; BROEDAERT, W.F. Isolation and characterization of a novel class of plant antimicrobial peptides form Mirabilis jalapa L. seeds. J. Biol. Chem., Baltimore, v. 267, p. 2228-2233, 1992.

CARVALHAES OLIVEIRA, J. Micologia médica. Rio de Janeiro: Ed. Control Lab. 1999. 225p.

CASTRO, J.M. Purgativos indigenas do Brasil. Rio de Janeiro: Typ. de Moreira, Maximiano \& C. 1878. 186p. [Dissertação de Mestrado. Faculdade de Medicina do Rio de Janeiro]. 
CAVALCANTE, P.B. E FRIKEL, P. A farmacopéia tiriyó/ Estudo étno-botânico. Belém: Gráfica Falangola Editora LTDA. $1973.157 \mathrm{p}$.

CYTED SUBPROGRAMA X. Pryecto X.7: Búsqueda y desarrollo de antifúngicos naturales y análogos. Rosário: CYTED-PIBEAFUN. 2003. $181 \mathrm{p}$.

D'AVILA, M.C. Da flora medicinal do Rio Grande do Sul. Porto Alegre, 1910; 155f. Dissertação Faculdade Livre de Medicina e Pharmacia de Porto Alegre.

DAFERERA, D.J.;ZIOGAS, B.N.; POLISSIOU, M.G. GCMS analysis of essential oils from some Greek aromatic plants and their fungitoxicity on Penicillium digitatum. J. Agric. Food Chem., Washington, v. 48, p. 2576-2581, 2000 .

DI STASI, L.C.; SANTOS, E.M.G.; SANTOS, D.M. DOS; HIRUMA, C.A. Plantas medicinais na Amazônia. São Paulo: Editora Universidade Estadual Paulista, 1989. 194p.

DI STASI, L.C. \& HIRUMA-LIMA, C.A. Plantas medicinais na Amazônia e na Mata Atlântica. 2. ed. São Paulo: Editora Universidade Estadual Paulista, 2002. 604p.

DIKSHIT, A.; NAQVI, A.A.; HUSAIN, A. Schinus molle: a new source of natural fungitoxicant. Appl. Environ. Micróbiol., Washington, v. 51, p. 1085-1088, 1986.

DUTRA, J. Anthelminticos brazileiros. 1887. Dissertação, Faculdade de Medicina do Rio de Janeiro, Rio de Janeiro.

EDMAN, J.C. Micologia Médica. In: BROOK, G.F.; BUTEL, J.S.; ORNSTON, L.N. Microbiologia médica. $20^{\mathrm{a}}$ ed. Rio de Janeiro: Guanabara Koogan, 1998. cap. 45, p. 420-443.

FREISE, F.W. Plantas medicinaes brasileiras. Boletim de Agricultura, v. 34, p.252-494, 1933.

GOTTLIEB, O.R.E.;BORIN,M.R.DEM.B. Quimiossistemática como ferramenta na busca de substâncias ativas. In: SIMÕES, C.M.O.; SCHENKEL, E.P.; GOSMANN,G.; MELLO, J.C.P.; MENTZ, L.A.; PETROVICK, P.R. Farmacognosia: da planta ao medicamento. 5 ed. Porto Alegre: Editora da UFRGS, 2003. cap. 5, p. 91-105.

GUARIM NETO, G. Plantas utilizadas na medicina popular do estado de Mato Grosso. Brasília: CNPq. $1987.58 \mathrm{p}$.
GUNDIDZA, M. Antimicrobial activity of essential oil from Schinus molle Linn. Cent. Afr. J. Med., Harare, v. 11, p. 231-234, 1993.

IPNI. The International Plant Names Index. Disponível em: $<$ http://www.ipni.org >. Acesso em: 01 out. 2004.

JUDD, W.S.; CAMPBELL, C.S.; KELLOGG, P.F. Plant Systematics/A Phylogenetic Approach. Massachusetts: Sinauer Associates, 1999. cap. 8, p. 161-419.

KARAYANNOPOULOU, G.; WEISS, J.; DAMJANOV, I. Detection of fungi in tissue sections by lectin histochemistry. Arch. Pathol. Lab. Med., Chicago, v. 112 , p. $746-748,1988$.

KOBAYASHI, A.; HAGIHARA, K.; KAJIYAMA, S.; KANZAKI, H.; KAWAZU, K. Antifungal compounds induced in the dual culture with Phytolacca americana callus and Botrys fabae. Z. Naturforsch., Tuebringen, v. 50, p. 398-402, 1995.

LACAZ, C.S.; PORTO, E.; MARTINS, J.E.C. Micologia médica: Fungos, actinomicetos e algas de interesse médico. 8 ed. São Paulo: Sarvier, 1991. 695 p.

LARRONDO, J.V.; AGUT, M.; CALVO-TORRAS, M.A. Antimicrobial activity of essences from labiates. Microbios, Cambridge, v. 82, p. 171-172, 1995.

LIU, Y.; LUO, J.; XU, C.; REN, F.; PENG, C.; WU, G.; ZHAO, J. Purification, characterization, and molecular cloning of the gen seed-specific antimicrobial protein from pokeweed. Plant. Physiol., San Diego, v. 122, p. 1015-1024, 2000.

LORENZI, H. E.; MATOS, F.J. DE A. Plantas medicinais no Brasil/ Nativas e exóticas. Nova Odessa: Instituto Plantarum. 2002. 512 p.

MANGENA, T.; MUYIMA, N.Y. Comparative evaluation of the antimicrobial activities of essences oils of Artemisia afra, Pteronia incana and Rosmarinus officinalis selected bacteria and yeast strains. Lett. Appl. Microbiol., Oxford, v. 28, p. 291296, 1999.

MARTIUS, C.P.V. Natureza, doenças, medicina e remédios dos índios brasileiros. São Paulo - Rio de Janeiro Recife - Porto Alegre: Companhia Editora Nacional, 1939. p. 233-269. 
MATOS, F.J. DE A. Farmácias vivas. 3 ed. Fortaleza: Edições UFC, 1998. 220 p.

MEDLINe-PubMed. Disponível em: $<$ http://www.ncbi.nlm.gov/ PubMed >. Acesso em: 18 set. 2004 a 18 out. 2004.

MOREIRA FILHO, H.E; GOLTCHER, A. Plantas medicinais I. Curitiba: Imprensa da Universidade Federal do Paraná, 1972. 103 p.

MOREIRA, N.J. Diccionario de plantas medicinaes brasileiras. Rio de Janeiro: Typographia do Correio Mercantil. 1862. 144p.

MOREIRA, N.J. Supplemento ao diccionario de plantas medicinaes brasileiras. Rio de Janeiro: Typgraphia Gonçalves Dias. 1871.57p.

OLIVEIRA, F.M.M. Vegetaes tonicos. Rio de Janeiro: Typographia da Revista do Exército Brasileiro, 1883. 142p.

OLIVEIRA, H.V. Systema de materia medica vegetal. Rio de Janeiro: Eduardo e Henrique Laemmert. 1854. 284 p.

ORTH, P.C. A flora medicinal do herbário Anchieta na exposição farroupilha. Porto Alegre: Globo. 1937. 58p.

PACIORNIK, E.F. A Planta nossa de cada dia; Plantas medicinais - Descrição \& Uso. 2 ed. Curitiba: Gráfica Copygraf. 1990, 92 p.

PANIZZI, L.; FLAMINI, G.; CIONI, P.L.; MORELLI, I. Composition and antimicrobial properties of essential oils of four Mediterranean Lamiaceae. J. Ethnopharmacol., Lausanne, v. 39, p. 167-170, 1993.

PARK, S.W.; LAWRENCE, C.B.; LINDEN, J.C., VIVANCO, J.M. Isolation and characterization of a novel ribosome-inactivating protein from root cultures of pokeweed and its mechanism of secretion from roots. Plant. Physiol., San Diego, v. 130, p. 164-178, 2002.

RATES, S.M.K. Plants as source of drugs. Toxicon, Oxford, v. 39, p. 603-613, 2001.

REITZ, R. Plantas medicinais de Santa Catarina. Anais botânicos do herbário Barbosa Rodrigues. Itajaí, v. 2(2), p. 71-116, 1950.
REITZ, R. Plantas medicinais de Santa Catarina. Anais botânicos do herbário Barbosa Rodrigues. Itajaí, v. 6(6), p. 259-300, 1954.

SANTOS, C.A. DE M.; TORRES, K.R., LEONART, R. Plantas medicinais/ herbarium, flora et scientia. $2 \mathrm{ed}$. São Paulo: Ícone, 1988. 160 p.

SHAO, F.; HU, Z.; XIONG, Y.M.; HUANG, Q.Z.; WANG, C.G.;ZHU, R.H.; WANG, D.C. Anew antifungal peptide from the seeds of Phytolacca americana characterization, amino acid sequence and cDNA cloning. Biochim. Biophys. Acta, Amsterdam, v. 1430, p. 262-268, 1999.

SHIN, S. Anti-Aspergillus activities of plant essential oils and their combination effects with ketoconazole or amphotericin B. Arch. Pharmacol. Res., Seoul, v. 26, p. 389-393, 2003.

SIDRIM, J.J.C.; DIÓGENES, M.J.N.; PAIXÃO, G.C. Dermatofitose. In: SIDRIM, J.J.C.; MOREIRA, J.L.B. Fundamentos clínicos e laboratoriais da micologia médica. Rio de Janeiro: Guanabara Koogan, 1999. p. 108-131.

SIMÕES, C.M.O. E SPITZER, V. Óleos Voláteis. In: SIMÕES, C.M.O.; SCHENKEL, E.P.; GOSMANN,G.; MELLO, J.C.P.; MENTZ, L.A.; PETROVICK, P.R. Farmacognosia: Da Planta ao Medicamento. 5 ed. Porto Alegre: Editora da UFRGS, 2003. cap. 18, p. 467-495.

SIMÕES, C.M.O., MENTZ, L.A.; SCHENKEL, E.P.; IRGANG, B.E.; STEHMANN, J.R. Plantas da medicina popular do Rio Grande do Sul. $5^{\mathrm{a}}$ ed. Porto Alegre: Editora UFRGS, 1998. 173 p.

VAN DEN BERG, M.E. Plantas Medicinais na Amazônial Contribuição ao Seu Conhecimento Sistemático. Belém: CNPq, 1982. 223 p.

$W^{3}$ TROPICOS . MOBOT. Missouri botanical garden. Disponível em: < http://www.mobot.org > Acesso em: 01 out. 2004.

YANG, S.W.; UBILLAS, R.; MCALPINE, J.; STAFFORD, A.; ECKER, D.M., TALBOT, M.K.B. Three new phenolic compounds from a manipulated plant cell culture, Mirabilis jalapa.J. Nat. Prod., Columbus, v. 64, p. 313-317, 2001. 
YUNES, R.A. E FILHO, V.C. Breve análise histórica da química da Plantas Medicinais: Sua importância na atual concepção de fármaco segundo os paradigmas ocidental e oriental. In: YUNES, R.A. E CALIXTO, J.B. Plantas Medicinais sob a ótica da química medicinal moderna. Chapecó: Argos, 2001. p. 17-44.

ZACCHINO, S. Estratégia para a descoberta de novos agentes antifúngicos. In: YUNES, R.A. E CALIXTO, J.B. Plantas medicinais sob a ótica da química medicinal moderna. Chapecó: Argos. 2001. p. 435-479.
ZOUBENKO, O.; HUDAK, K.; TUMER, N.E. A non-toxic pokeweed antiviral protein mutant inhibits pathogen infection via a novel salicylic acid-independent pathway. Plant. Mol. Biol., Dordrecht, v. 44, p. 219-229, 2000.

ZOUBENKO, O.; UCKUN, F.; HUR, Y.; CHET, I.; TUMER, N. Plant resistance to fungal infection induced by nontoxic pokeweed antiviral protein mutants. Nat. Biotechnol., New York, v. 15, p. 992-996, 1997.

Recebido para publicação em 29 de novembro de 2004. Aceito para publicação em 07 de junho de 2006. 